\title{
Soluble mediators regulating immunity in early life
}

\author{
Matthew Aaron Pettengill ${ }^{1,2}$, Simon Daniël van Haren ${ }^{1,2}$ and Ofer Levy ${ }^{1,2}$ * \\ 1 Department of Medicine, Division of Infectious Diseases, Boston Children's Hospital, Boston, MA, USA \\ 2 Harvard Medical School, Boston, MA, USA
}

Edited by:

Tobias R. Kollmann, University of

British Columbia, Canada

\section{Reviewed by:}

Fabienne Willems, Université Libre de

Bruxelles, Belgium

Martin O. C. Ota, World Health

Organization, Congo

\section{*Correspondence:}

Ofer Levy, Department of Medicine, Division of Infectious Diseases,

Boston Children's Hospital, Boston, MA 02115, USA

e-mail: ofer.levy@childrens.

harvard.edu
Soluble factors in blood plasma have a substantial impact on both the innate and adaptive immune responses. The complement system, antibodies, and anti-microbial proteins and peptides can directly interact with potential pathogens, protecting against systemic infection. Levels of these innate effector proteins are generally lower in neonatal circulation at term delivery than in adults, and lower still at preterm delivery. The extracellular environment also has a critical influence on immune cell maturation, activation, and effector functions, and many of the factors in plasma, including hormones, vitamins, and purines, have been shown to influence these processes for leukocytes of both the innate and adaptive immune systems. The ontogeny of plasma factors can be viewed in the context of a lower effectiveness of immune responses to infection and immunization in early life, which may be influenced by the striking neonatal deficiency of complement system proteins or enhanced neonatal production of the anti-inflammatory cytokine IL-10, among other ontogenic differences. Accordingly, we survey here a number of soluble mediators in plasma for which age-dependent differences in abundance may influence the ontogeny of immune function, particularly direct innate interaction and skewing of adaptive lymphocyte activity in response to infectious microorganisms and adjuvanted vaccines.

Keywords: plasma, serum, immunoregulatory, immune, neonatal

\section{INTRODUCTION}

Plasma, the fluid component of blood, is a complex mixture of water, proteins, electrolytes, lipids, sugars, hormones, and gas molecules. Plasma components also infiltrate the extravascular space and tissues and have a considerable influence on many physiological processes, including being an efficient transport medium for systemic signaling. The study of plasma is complicated by the complexity of its composition - several hundred distinct proteins (1), and hundreds of small molecules (2) have been analyzed in plasma by mass spectrometry. While many of these molecules have uncharacterized functions, there is a growing evidence that many of the factors in plasma that are well-characterized help to shape the response to infection, inflammation, and immunity (3-6). Many plasma molecules vary in concentration as a function of age, and we seek here to describe both the immunoregulatory capacity of some of the best-studied molecules and the age-dependent regulation of their abundance in circulation (see Table 1) in the context of well-described deficits in neonatal immune system function $(7,8)$. Particular consideration is given to molecules, including cytokines, hormones, lipids, vitamins, and purines that influence the differentiation, activation, and effector functions of subsets of T cells (Figure 1). Additionally, several classes of proteins, including immunoglobulins (Igs), the complement system, and anti-microbial proteins and peptides (APPs), aid in the innate response to invading microorganisms and display age-dependent maturation (Figure 1). The critical role that plasma components play in immune function also highlights the importance of including autologous or pooled species- and age-specific plasma in the extracellular milieu in in vitro assay systems, instead of xenologous media (e.g., fetal calf serum), which is more commonly utilized.

\section{CYTOKINES}

The increased susceptibility of newborns to infection is at least partially due to their impaired ability to mount a T-helper 1 (Th1) response (139). Over the last decade, several in vitro and ex vivo studies have demonstrated an impairment of neonatal leukocytes to produce Th1-polarizing cytokines, such as IL-12p70 and tumornecrosis factor alpha (TNF- $\alpha$ ), as compared to adult leukocytes (11, 24-26). A comparison of newborn and adult serum levels of the T-cell polarizing cytokines TNF- $\alpha$ and IL- 6 reveals that the ratio between these cytokines during the first 7 days of life is significantly different from adults (11). TNF- $\alpha$, a Th1-polarizing cytokine, is consistently low in cord blood and peripheral blood drawn during the first days of life, as compared to adult blood. In marked contrast to TNF- $\alpha$, IL- 6 levels in cord blood are higher than in adult blood, and continue to rise during the first days of life. IL-6 is a cytokine that is capable of inducing Th2-polarization (9) or Th17 polarization, in combination with IL-23 and TGF- $\beta$ (140). In addition, it induces the production of acute-phase proteins C-reactive protein (CRP) and LPS-binding protein (LBP) (141), and has anti-inflammatory properties such as inhibition of neutrophil migration $(10,142)$.

In addition to distinct basal levels of serum cytokines, newborns also demonstrate a distinct pattern of cytokine production after immunization, including impairment in the production of the pro-inflammatory/Th1-polarizing cytokine IFN- $\gamma$ to many vaccines (33-35), with the possible exception of bacille CalmetteGuérin (BCG) (143). IFN- $\gamma$ is expressed by Th1 cells, activating macrophages to kill microbes, promoting leukocyte cytotoxicity, and inducing apoptosis of epithelial cells in the skin and mucosa $(29,30)$ In addition to its role in the development of a 
Table 1 | Age-dependent changes in various soluble factors that influence innate and adaptive immune function, and list of references to literature regarding their concentrations in blood (Levels) and their function related to immune cell function (function).

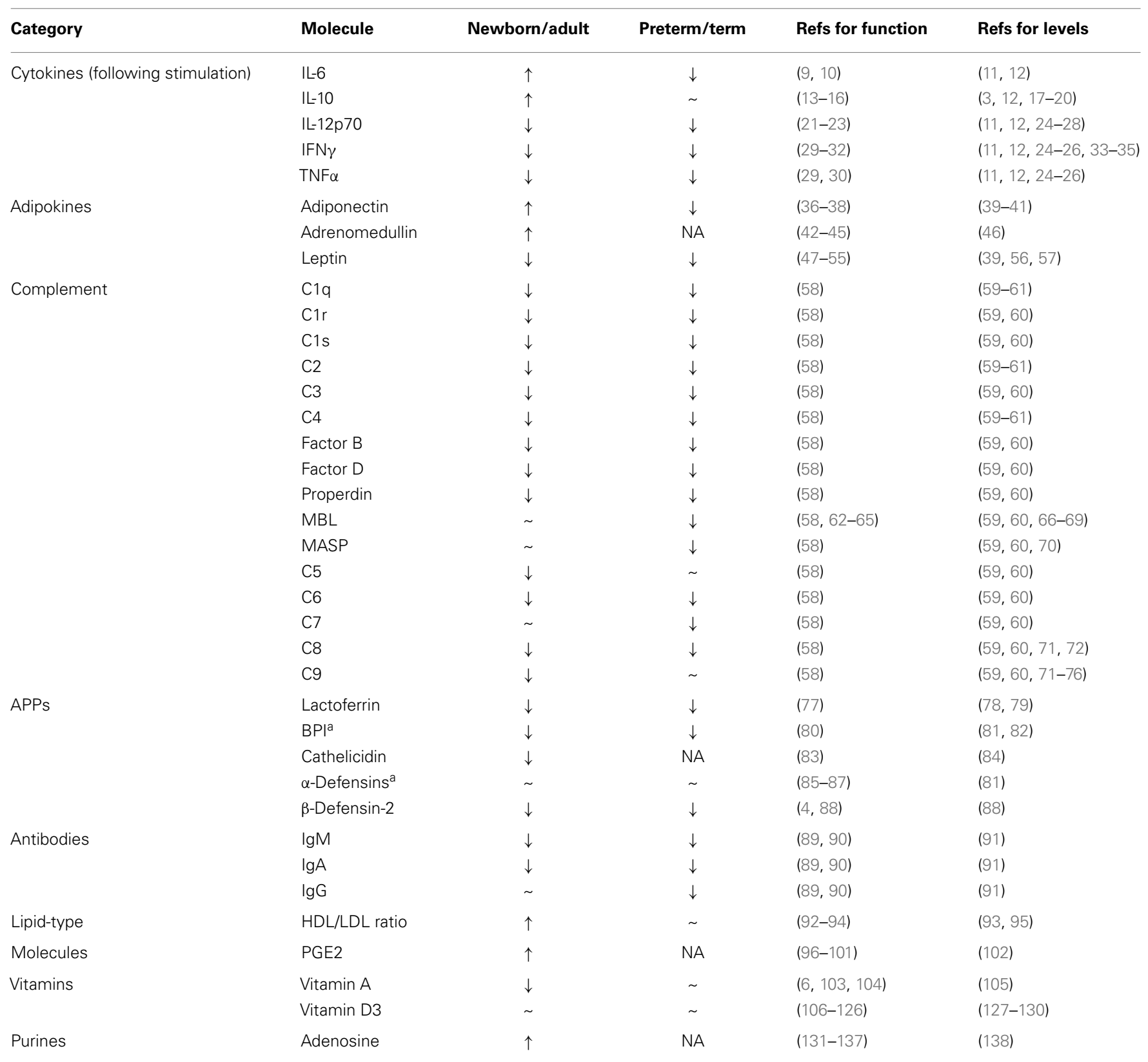

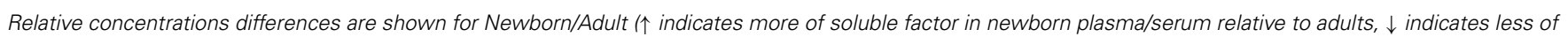
soluble factor in newborn plasma/serum relative to adults) and Preterm/Term ( $\uparrow$ indicates more of soluble factor in preterm plasma/serum relative to term subjects,

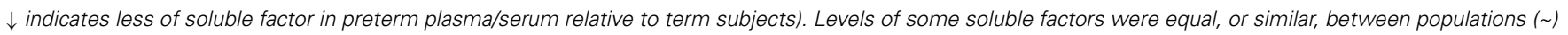
or were not reported in comparison between the two populations (NA).

${ }^{a} \mathrm{BPI}$ and $\alpha$-defensins relative concentrations in neutrophil granules.

Th1 response and B-cell isotype switching (31), IFN- $\gamma$ regulates MHC class I and II protein expression and antigen presentation as well (32). Overall, neonatal impairment in infection- or immunization-induced IFN- $\gamma$ production is believed to be an important contributing factor in their susceptibility to intracellular pathogens. In addition, mononuclear cells from preterm newborn blood produce significantly less IFN- $\gamma$ following in vitro stimulation than mononuclear cells from term newborns (27).
Several in vitro studies comparing neonatal cord and adult peripheral blood mononuclear cells have demonstrated a discordance in the secretion of T-cell polarizing cytokines after stimulation with Toll-Like Receptor (TLR) agonists, providing an explanation for the impairment in IFN- $\gamma$ production by Th 1 cells that is also observed in vitro (144). Whole blood assays comparing cord blood and adult peripheral blood have confirmed that newborn cells produce less TNF- $\alpha$ in response to common 


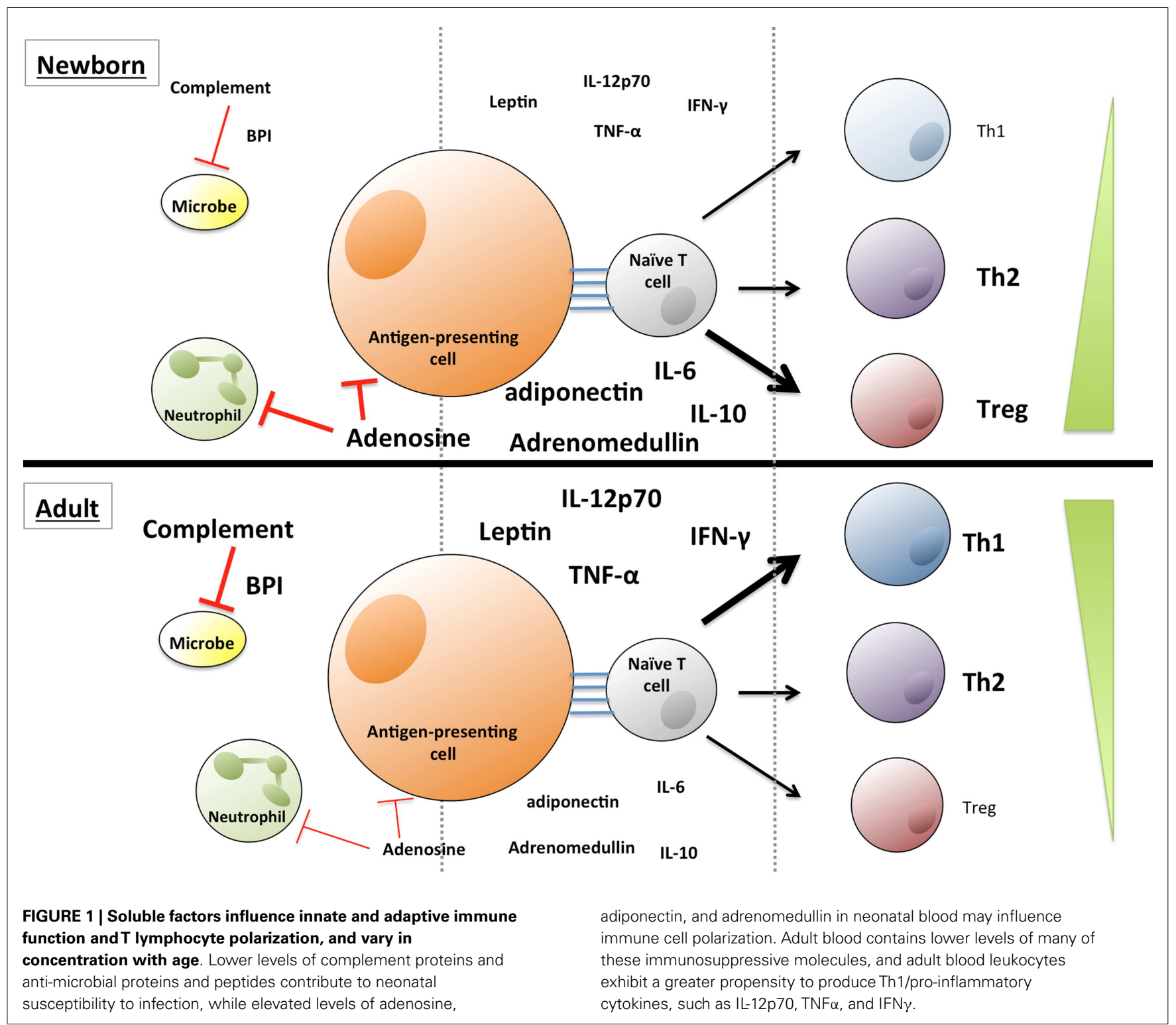

TLR agonists, such as polyinosinic:polycytidylic acid (Poly I:C, TLR3), $\mathrm{Pam}_{3} \mathrm{CSK}_{4}$ (TLR1/2), and lipopolysaccharide (LPS, TLR4) $(138,144,145)$. Later studies supported these observations and established that newborn monocytes as well as monocyte-derived dendritic cells (MoDCs) produce less TNF- $\alpha$ and more IL-6 in response to these molecules $(25,28)$. In addition to TNF$\alpha$, newborn MoDCs also demonstrated an impairment in the production of another T-cell polarizing cytokine, IL-12p70, but appeared to be competent if not superior in the production of IL-1 $\beta(144,146)$. Interestingly, newborn monocytes and MoDCs are able to produce adult-like amounts of TNF- $\alpha$, Il-1 $\beta$, and IL12 p70 in response to TLR7/8 agonists, such as ssRNA or the purine analog $\mathrm{R} 848(28,146,147)$. Leukocytes from preterm newborns produce less TNF- $\alpha$, IL-6, and IL-12/IL-23p40 than term subjects, but similar levels of IL-10, in response to TLR stimulation (12).
IL- $1 \beta$ is a potent pro-inflammatory cytokine that acts as an endogenous pyrogen. It has diverse potentiating effects on cell proliferation, differentiation, and function of many innate and specific immunocompetent cells and may mediate inflammatory diseases by initiating and potentiating immune and inflammatory responses (148). IL- $1 \beta$ also can also act synergistically in combination with IL-6 and IL-23, enabling the expression of ROR $\gamma \mathrm{T}$, which is an important step in the early development of Th17 cells (149).

Newborn leukocytes demonstrate an impaired ability to produce IL-12p70, a heterodimer that consists of a $35 \mathrm{kDa}$ light chain (p35) and a $40 \mathrm{kDa}$ heavy chain (p40). It is produced by activated monocytes, macrophages, neutrophils, microglia, and dendritic cells (DCs) (21). The heterodimer, IL-12p70, is a Th1-polarizing cytokine $(22,23)$. Production of the p35 subunit is impaired in newborn monocyte-derived DCs after treatment with LPS, correlating with a lack of nucleosome remodeling necessary for 
transcription factor Sp1 to gain access to the $\mathrm{p} 35$ promoter (150). Diminished production of the p35 subunit of IL-12p70 was also seen in newborn myeloid DCs treated with HCMV (151), and neonatal myeloid DCs produced not only less IL12p35, but also less IFN- $\beta$, as compared to adult DCs.

The molecular mechanism underlying the bias against Th1polarizing cytokines is under active investigation. A growing literature documents that age-specific soluble plasma factors exert marked effects on TLR-mediated Th-polarizing responses (3, 25, $28,102)$. Neonatal plasma contains high concentrations of adenosine $(138,152)$ (see Purines), an immunosuppressive metabolite that induces cyclic adenosine monophosphate in leukocytes and thereby inhibits Th1-poalrizing cytokine production. Newborn plasma enhances TLR4-mediated IL-10 production in newborn as well as adult mononuclear cells (102). This study also emphasizes that, although intrinsic cellular differences exist between newborn and adult immune cells $(150,153,154)$, it is important to culture cells in autologous plasma when studying differences between age groups. In contrast, a study of neonatal mononuclear cells cultured in fetal bovine serum demonstrated impaired TLR4-mediated IL-10 production in newborn cells compared to adult cells (17). Besides macrophages and DCs, newborn regulatory B cells (Bregs) also produce IL-10 in response to TLR activation (155). Newborn cord plasma IL-10 concentrations are higher in newborns than in adults, both at baseline and after infection $(3,18-20)$. IL-10 inhibits the expression of co-stimulatory molecules on DCs (13), inhibits the expression of several proinflammatory cytokines (14) and inhibits the activation of T cells through CD28 (15). Conversely, IL-10 also enhances antibody (Ab) production by promoting B-cell survival and differentiation and increasing the production of IgG4 Abs (13). IL-10 enhances generation of regulatory $\mathrm{T}$ cells (Tregs) that inhibit a neonatal immune response to BCG $(16,19)$. How elevated levels of IL-10 affect neonatal defense against other pathogens is unclear, but is likely context dependent. Both beneficial and deleterious effects of elevated IL-10 in neonatal mice were noted upon infection with group B Streptococcus (GBS) $(156,157)$. On the one hand, elevated levels of IL-10 prior to GBS infection result in increased survival by reducing sepsis (156). On the other hand, elevated IL-10 levels after GBS infection can inhibit the migration of neutrophils to infected organs, resulting in increased mortality (157). Neonatal mice are impaired in their response to thymus-independent antigens, ascribed to IL10 mediated suppression of neonatal B-cell production of IL- $1 \beta$ and IL-6 (20).

As a consequence of the distinct production of T-cell polarizing cytokines by newborn mononuclear cells, the adaptive immune system of newborns is skewed toward the development of Th2 and Treg cells rather than Th1 cells. Elevated levels of IL-1 $\beta$ and IL-6 production result in a potent acute-phase response, leading to elevated serum levels of CRP, LBP, and anti-microbial proteins and peptides (158-160), and can polarize naïve CD4 + T cells to differentiate to Th2 or Th17 cells, which can protect against bacterial or fungal infections. However, impaired production of proinflammatory/Th1-polarizing cytokines such as TNF- $\alpha$, IFN- $\gamma$, and IL-12p70 impair the newborns' ability to mount a protective Th1 response, leaving them vulnerable to viral infections.

\section{THE COMPLEMENT SYSTEM}

The complement system is a triggered-enzyme cascade of plasma proteins that deposit components with opsonin function on the surface of microbes and to membrane disruption and cell lysis on a subset of these targets (58). Complement was so named as it enhances opsonization and killing of bacteria by Ab, although it is now known that complement deposition also occurs in the absence of $\mathrm{Ab}$. There are three well-defined pathways of complement activation, named for the types of molecules that trigger the cascade by binding to conserved polysaccharide patterns on the surfaces of microbes: the classical pathway, initiated by Ab binding; the mannose-binding lectin (MBL) pathway, which follows MBL recognition of distinct mannose and fucose spacing on the surface of bacteria; and the alternative pathway in which spontaneous cleavage of the complement protein $\mathrm{C} 3$ can lead to its deposition on the surface of microbes. These distinct early events in complement activation converge on the central event common to all three pathways - covalent attachment of the C3 convertase on the surface of the microorganism. C3 convertase cleavage of C3 generates $\mathrm{C} 3 \mathrm{~b}$, the primary effector molecule of the complement system, and cleavage product $\mathrm{C} 3 \mathrm{a}$, a mediator of inflammation. $\mathrm{C} 3 \mathrm{~b}$ bound to the $\mathrm{C} 3$ convertase on the surface of the microorganism comprises a C5 convertase, leading to C5 cleavage and $\mathrm{C} 5 \mathrm{~b}$ attachment to the microbial surface, and the release of C5a, a peptide mediator of inflammation and potent chemokine that leads to phagocyte recruitment. C5b triggers the assembly of a membrane-attack complex that utilizes complement system proteins $\mathrm{C} 6, \mathrm{C} 7, \mathrm{C} 8$, and $\mathrm{C} 9$, to damage the membrane of susceptible bacteria. There are two primary clinical evaluations of complement function: the complement hemolysis $50 \%$ assay ( $\mathrm{CH} 50)$ in which patient serum is co-incubated with sheep erythrocytes pretreated with rabbit anti-sheep Abs and the alternative pathway hemolysis $50 \%$ assay (AP50) for which patient serum is incubated with rabbit erythrocytes in the presence of calcium chelators, which isolate the alternative pathway by inhibiting the classical and MBL pathways. Both complement function assays evaluate erythrocyte lysis mediated by dilutions of serum.

Multiple studies have characterized the ontogeny of complement expression in human plasma. CH50 is $\sim 57-75 \%$ of adult controls for preterm subjects and 69\% of adult controls for term subjects (59). AP50 values were 49,53, and $60 \%$ of adult controls for extreme preterm (28-33 weeks GA), preterm (34-36 weeks GA), and term subjects, respectively. A review of $>12$ studies including preterm or term neonates, or both, shows that $\mathrm{CH} 50$ values for preterm subjects at GA $26-27$ weeks are $\sim 32-36 \%$ of adult controls, and that the average $\mathrm{CH} 50$ for term neonates, giving equal weight to each independent study, was $\sim 59 \%$ of adult controls (60). The average AP50 for term neonates was $\sim 58 \%$ of adult controls, and although fewer studies evaluated AP50 in preterm neonates, the values were modestly lower than those for term neonates (60). One report showed a modest increase in $\mathrm{CH} 50$ activity in older adult patients (161), possibly due to increases in $\mathrm{C} 4$ and $\mathrm{C} 9$ proteins with increasing age, although not all complement components were evaluated (noted increases were gradual out to 70-79 years of age).

Levels of most individual complement proteins are lower in preterm and term neonates compared to adult levels, and while we 
will highlight a few examples here, the reader is referred to a recent review on the topic (60). One study demonstrated that classical and MBL pathway proteins $\mathrm{C} 2$ and $\mathrm{C} 4$ reach adult levels by 1 and 6 months of life, respectively, while classical pathway protein $\mathrm{Clq}$ did not reach adult levels until 18-21 months of age (61). Particularly striking among the deficiencies in levels of individual proteins are membrane-attack complex proteins C8 and C9. Levels of C8 in preterm subjects have been reported at $29 \%$ of adult levels $(59,71)$, and in term, subjects in the range of $36-38 \%$ of adult levels $(59,71$, 72), while neonatal levels of C9 of have been more variable depending on the study, ranging from 11 to $84 \%$ of adult levels $(59,71-76)$. Low levels of membrane-attack complex proteins in neonates may represent a delicate balance, as C9 contributes to central nervous system and respiratory pathology related to hypoxia-ischemia (162, 163), but diminished levels of membrane-attack complex components may increase susceptibility to infection. Regarding the developmental regulation of complement proteins, it is noteworthy that while nearly all complement proteins that are found at lower levels in neonates are produced in the liver, C7, which is only modestly reduced in preterm neonates, and is at adult levels in term neonates, is not produced in the liver, but is rather largely neutrophil-derived (164).

It is unclear whether or not levels of MBL in circulation vary significantly with gestational age, with several studies demonstrating increases in MBL concentration with increasing gestational age (66-68), but a large recent study showing no such relationship (69) while still demonstrating GA dependent increases in MBLMASP complex activity (70). What is clear is that MBL levels in plasma are highly variable due to well-characterized hereditary mutations, which effect up to $40 \%$ of the population $(165,166)$. Low MBL levels have been associated with increased risk of infection in adult populations $(62,63)$, and there is an association of MBL2 gene mutations with increased mortality and sepsis $(64,65)$. While one study showed no increased mortality in neonates with low MBL levels (167), several other studies have demonstrated that neonates with infections or sepsis have lower average levels of MBL or increased representation of genetic deficiency of MBL than healthy counterparts $(66,70,168-170)$. Newborns may be more sensitive to genetic deficiency of MBL due to limited capacity to compensate with other pathways of complement activation. Of note, the strikingly high accumulation of genetic deficiency of MBL in humans suggests that, at least historically, there has been little evolutionary pressure on maintaining $\mathrm{MBL}$ activity in this population, or that this genetic locus may be subject to a variety of conflicting pressures. While this is surprising, given the strong association of low MBL levels and increased risk of infection, it may be that relatively recent changes in human health care practices are associated with the increased risk, such as biofilm formation on indwelling lines and foreign materials, or nosocomial infection, factors, which are particularly applicable to hospitalized neonatal subjects in recent decades, and to which a lower percentage of the human population was exposed in previous generations.

\section{ANTI-MICROBIAL PROTEINS AND PEPTIDES}

Anti-microbial proteins and peptides play a critical role in innate immunity by directly combating susceptible pathogens and by recruiting and activating leukocytes at sites of infection. Cationic
APPs that are present in blood plasma include larger proteins such as lactoferrin and bactericidal/permeability-increasing protein (BPI); peptides such as cathelicidin; $\alpha$-defensins; and $\beta$-defensins.

Lactoferrin is present in mammalian secretory fluids, and also in blood plasma and neutrophil secondary granules, and has antimicrobial functions that include sequestration of iron, binding and inactivation of endotoxin, and oxidation of bacterial membrane molecules leading to membrane integrity loss (77). Lactoferrin is found at high concentrations in breast milk in particular, and may contribute to innate immune protection in early life in breast-fed children. Levels of lactoferrin are lower, however, in newborn neutrophils relative to adult neutrophils, possibly reflecting degranulation during the stress of birth (78), and plasma lactoferrin increases with increasing gestational age in preterm subjects (79). Levels of BPI are also lower in neutrophils isolated from newborns, compared to those from adult subjects (81), and lower in neutrophils from preterm newborns compared to term newborns (82). BPI is particularly active against Gram-negative bacteria and functions to neutralize endotoxin and permeabilize sensitive bacteria (80). Replenishing BPI, along with oral fluoroquinolone antibiotic, in mice rendered neutropenic by total body irradiation hastens bone marrow recovery and reduces radiation-induced mortality (171). Adjunctive recombinant BPI therapy appears to improve outcomes in children with meningococcal sepsis (172). Such studies suggest that replenishing levels of APPs in select clinical settings may be of benefit.

Human cathelicidin anti-microbial peptide 18 (hCAP-18, also called LL-37) is produced by epithelial cells, macrophages, and neutrophils, and can be upregulated in response to infection and by stimulation with the hormonally active form of vitamin D (1,25$(\mathrm{OH}) 2 \mathrm{D} 3)$ (83). Lower serum levels of cathelicidin are associated with increased severity of acute respiratory infection in children aged 0-24 months presenting with bronchiolitis (173). Newborns have lower plasma levels of cathelicidin compared to maternal levels, with vaginal delivery associated with higher cathelicidin levels in mother and newborn compared to caesarian section (84).

$\alpha$-Defensins and $\beta$-defensins are cationic peptides produced by a wide variety of organisms with anti-infective activity against viruses (85), bacteria (86), and fungi (87). There are $6 \alpha$-defensins, four of which are predominately produced by neutrophils (human neutrophil peptides 1-4, HNP1-4), which are expressed at adultlike levels at birth (81). $\beta$-Defensins are produced primarily by epithelial cells, macrophages, and neutrophils, and in addition to direct anti-microbial activity related to microbial membrane disruption, also function as chemotactic peptides to recruit particular classes of leukocytes (4). Low serum levels of $\beta$-defensin-2 have been associated with increased risk of developing sepsis in preterm neonates (88). This study also noted that $\beta$-defensin- 2 is higher in term than in preterm serum, and that levels of $\beta$-defensin- 2 correlated with gestational age and weight. Overall, APPs likely play an important role in fetal and neonatal innate immunity, helping to regulate colonization and resisting infection (174).

\section{ANTIBODIES}

The composition of Ig isotypes in newborns and infants is distinct from that of adults, with IgG, initially primarily of maternal origin, near adult levels but rapidly declining to a nadir of circulating 
IgG at about 3 months of age, and significantly reduced levels of IgA and IgM at birth that gradually rise to near adult levels by puberty (91). Fetal B cells begin producing small amounts of Ig in the 20th week of gestation, predominantly IgM antibodies (Abs), with limited VH-gene segment usage $(175,176)$. The majority of circulating Abs in newborns is, however, of maternal origin. Maternal Igs, which are transported across the placenta during pregnancy, contribute to the protection of infants from infectious diseases during the first months of life. In addition to their role in binding antigen (89), Igs also play an important role in regulating adaptive immune responses through their interaction with Fc receptors (FcRs) (90). As a result, the presence of Igs during the first months of life can influence how newborns and infants respond to vaccination.

Maternal antibodies (MatAbs) are transported across the fetomaternal interface with the help of receptors that are specific for the Fc-portion of IgG: FcRn and Fc $\gamma$ R I, II, and III (177). Accordingly, only Igs of the IgG isotype are transported across the placenta. Of the different IgG subclasses, IgG1 is the most efficiently transported subclass and IgG2 is the least (178). In general, IgG is the most potent of all isotypes with respect to Fc-receptor binding on macrophages and NK cells. It is also able to activate complement, though less potently than IgM.

As MatAbs are a crucial component of the humoral immune system of newborns, it is important to note that the effector function of these Abs changes dramatically during pregnancy. The Th2-polarized cytokine environment during pregnancy drives an essential change in the glycosylation pattern of the mothers' IgG, resulting increasing asymmetrically glycosylated IgG Abs (179). These Abs possess a mannose-rich oligosaccharide residue bound to one of the Fab regions, making them unable to activate immunoeffector mechanisms, such as complement fixation, and clearance of antigens and phagocytosis (179). Because the glycosylation does not affect binding to FcRn, asymmetrically glycosylated Abs can be found in the fetal circulation as well (180). These asymmetrical MatAbs can of course still confer protection by binding to pathogenic antigens.

The protective effects of MatAbs on the newborn depend on the gestational age of the fetus at birth. Premature infants are often vulnerable to infections, partly because of the low transplacental transfer of MatAbs. For example, transplacental transfer of MatAbs against varicella zoster virus (VZV) is significantly lower in preterm infants born at $\leq 28$ weeks gestational age, compared with those in preterm infants 29-35 weeks gestational age and term infants (181). Similarly, protective, neutralizing Abs specific for Rubella, or cytomegalovirus (CMV) are present at higher concentrations in the circulation of full-term infants, as compared to preterm infants, contributing to preterm susceptibility to these viruses $(182,183)$.

As MatAbs may contribute to protection against infections during the first 6 months of life, maternal immunization has been a strategy of interest. Indeed, this approach has proved safe and beneficial to immunize mothers, such as in the case of Tdap, but this approach may reduce the infants' response to their own primary Tdap immunization at 6 months (184). Inhibition of vaccine efficacy by MatAbs is particularly evident with live viral vaccines such as measles or respiratory syncytial virus (RSV) $(185,186)$, but has also been observed with a conjugate vaccine against Neisseria meningitidis (187). Proposed mechanisms of inhibition are epitope masking and B-cell inhibition by cross-linking of the B-cell receptor with Fc $\gamma$ RIIB.

\section{HORMONES}

Hormones regulate physiological functions of many cells types including leukocytes. Two critical hormones that circulate in plasma and influence immune cell function are leptin and adiponectin, known as "adipokines" - cytokines produced primarily by adipose tissue. Leptin is a $16 \mathrm{kDa}$ protein hormone that regulates hunger/satiety sensation and metabolic rate, and is produced in relation to the mass of adipose tissue. Leptin concentrations fluctuate considerably based in part on satiety, which increases leptin, or starvation, which decreases leptin. Adiponectin is a $\sim 30 \mathrm{kDa}$ metabolic regulatory protein hormone that modulates glucose levels and fatty acid oxidation (188). Intriguingly, stimulation of the leptin receptor activates signal transducer and activator of transcription 3 (STAT3), STAT5, and Janus kinase 2 (JAK2) inducing gene transcription via IL-6-responsive gene elements (189). Adiponectin shares sequence homology with a complement system protein $(\mathrm{Clq})$ and structural homology with TNF family members (190). The full-length LepRb leptin receptor is expressed in T cells, NK cells, macrophages, and polymorphonuclear cells (5). Genetic deficiency of leptin in human beings has been associated with reduced CD4 T-cell populations, hyporesponsive T cells, and lower levels of IFN $\gamma$, while increasing levels of transforming growth factor $\beta$ (TGF $\beta$ ), conditions which were reversed with leptin replacement therapy (47). Similar immunological dysfunction has been noted in subjects with leptin receptor deficiency (48, 49). In mice, leptin protects against infection with Mycobacterium tuberculosis (50), Klebsiella pneumonia (51), and Streptococcus pneumoniae (52-54). In vitro stimulation of cord blood and adult T cells with leptin leads to upregulation of IFN $\gamma$, IL-2, IL-4, and IL-10, and interestingly significantly more IFN $\gamma$ was produced by female cord blood $\mathrm{T}$ cells than from male (55). Circulating leptin levels at birth are lower than, and influenced by, maternal levels of leptin (39) and are higher in term neonates than in preterm neonates (56). Leptin levels drop in the first days of life $(39,56)$ and then gradually rise with age peaking at puberty (57). There is moderate sex dimorphism in serum leptin levels - females having significantly higher levels of leptin in older age groups $(56,57)$.

Adiponectin is found at very high levels in serum, in the range of $\sim 10 \mu \mathrm{g} / \mathrm{ml}(40)$, is elevated at birth compared to maternal levels (41), and does not drop in the first 4 days of life (39). Circulating adiponectin levels are lower in preterm newborns than term newborns (191), and levels decrease from term birth to approximately adult levels by $6-10$ years of age (40). Adiponectin induces anti-inflammatory IL-10 production from human monocytes, macrophages, and DCs, while suppressing TNF $\alpha$ production (36). Adiponectin receptors are upregulated on $\mathrm{T}$ cells following activation, and adiponectin stimulation of CD8 $+\mathrm{T}$ cells inhibits proliferation and IL-2 production, as well as production of the pro-inflammatory cytokines IFN- $\gamma$ and TNF $\alpha$ (37). Additionally, adiponectin suppresses DC IL-12p40 production and co-stimulatory molecule expression, and in DC/T-cell co-cultures favor the generation of regulatory $\mathrm{T}$ cells (38). 
Adrenomedullin (AM), a cleavage product of preproadrenomedullin, is a circulatory neuropeptide hormone. AM stimulates calcitonin receptor-like receptor (CALCRL) or receptor activity-modifying proteins 2 and 3 (RAMP2 and RAMP3), leading to increased cyclic-AMP (42). AM is generated by a variety of leukocytes in response to inflammatory stimuli (43), and also has direct anti-microbial activity (44). Pretreatment of mice, or murine macrophages, with AM before challenge with endotoxin suppressed the production of pro-inflammatory cytokines (e.g., $\mathrm{TNF} \alpha, \mathrm{IL}-1 \beta$, CCL5, IL-12) while promoting IL-10 production, and reduced mortality due to cecal-ligation and puncture-induced sepsis (45). Plasma levels of AM are elevated in pregnant mothers and in cord blood relative to non-pregnant female levels (46), which could potentially influence the suppression of proinflammatory cytokine production that has been noted in both neonates and late in pregnancy for mothers.

Sex hormones (estrogen, progesterone, and testosterone) can also influence the immune system (192-194), which may contribute to gender differences in responses to infection and immunization (195-197), but they have primarily been studied in this context in animal studies utilizing genetically modified organisms with a complete lack of various enzymes or receptors involved in steroid production or signaling. Androgens (including testosterone) generally suppress immune cell function in vitro, while estrogen may enhance Ab production (198). Estrogen (estradiol) in females and testosterone in males are found at relatively low levels at birth, increase after puberty reaching their highest levels during teenage years $(10,33,34,141,142)$, and diminish thereafter (57), but it is unknown if lower levels of these hormones at birth influences immune cell activity. Increased levels of progesterone during pregnancy may modulate the Th1/Th2 profile of adaptive responses - favoring production IL-4 and IL-5 and Th2 bias $(199,200)$. Progesterone levels are elevated at birth (presumably of maternal origin) in both genders relative to later in childhood, but not to levels found in female adults (201).

\section{LIPIDS AND LIPID-TYPE MOLECULES}

Pregnancy affects maternal metabolism of various substrates and nutrients including lipids, which affects innate immunity. Changes in the maternal plasma lipid profile include increased concentrations of fatty acids, triglycerides, and cholesterol and by changes in the concentration and composition of lipoproteins (202-204). Newborns have lower levels of total cholesterol, with a preponderance of high-density lipoprotein (HDL), as opposed to the abundance of low-density lipoprotein (LDL) in adult blood (92-94). Moreover, the composition of fetal HDL particles is distinct from that of adults. Fetal HDL particles are enriched in apolipoprotein $\mathrm{E}$ (apoE) and have diminished levels of apoA-1 and apoL, as compared to maternal HDL (93). The lipoprotein composition of fetal HDL can vary between male and female newborns as well, as female newborns have higher levels of HDL-cholesterol than male newborns $(205,206)$. Distinct fetal HDL composition affects fetal endothelial cell function and tissue growth (94), as well as the developing immune system. In general, the elevated ratio of HDL/LDL in newborns is associated with immune suppression (93). Preterm newborns have elevated levels of cholesterol, but similar HDL/LDL ratios compared to term newborns (95). HDL is an acute-phase reactant that can bind and neutralize LPS. IL-6 can alter the composition of HDL particles, resulting in less apoA-1 expression and Serum paraoxonase/arylesterase 1 (PON1) activity, in turn reducing its anti-oxidant properties (207). Given HDL's roles in clearance of endotoxin (208), reduced levels of apoA-1 in newborns may affect their susceptibility to sepsis. Most other immune-modulating activities of HDL, such as down-regulation of co-stimulatory molecules on macrophages and DCs (209) and TNF- $\alpha$-induced expression of adhesion molecules on endothelial cells (210) have been largely ascribed to the presence of apoA-1. Despite the apparent reduction of apoA-1 in neonatal HDL particles, newborn HDL is also immunosuppressive via the activity of apoE, which has the ability to inhibit T-cell proliferation and nitric oxide synthesis by macrophages $(211,212)$.

Another important lipid mediator of the newborn immune system is prostaglandin $\mathrm{E}_{2}\left(\mathrm{PGE}_{2}\right) . \mathrm{PGE}_{2}$ is a prostanoid that is generated from arachidonic acid by the action of cyclooxygenase isoenzymes. It can function in both the promotion and the resolution of inflammation. PGE2 signals via G-protein coupled Prostaglandin E receptors expressed on a variety of immune cells, including DCs and T cells $(96,97) . \mathrm{PGE}_{2}$ is elevated in newborn plasma, as compared to adults (102). Although PGE $_{2}$ inhibits IL-12p70 production (98), it is not solely responsible for impaired TLR4mediated IL-12p70 production in newborns as additional yet to be identified soluble plasma components appear to contribute to that activity (102). The pleiotropic nature of $\mathrm{PGE}_{2}$ precludes a simple analysis of its overall affect on the newborn immune system. In general, $\mathrm{PGE}_{2}$ inhibits Th1-polarizing cytokine production by DCs and macrophages, changes DC morphology, resulting in a loss of podosome formation and co-stimulatory receptor expression (99-101). Paradoxically, $\mathrm{PGE}_{2}$ may also increase production of Th1-polarizing cytokines and DC function $(213,214)$. These apparently conflicting in vitro activities may be due to distinct effects that $\mathrm{PGE}_{2}$ exerts over time and at different $\mathrm{DC}$ : $\mathrm{T}$ cell ratios in co-culture $(215,216)$, as PGE2 can also act directly on CD4+ T cells, promoting the expansion of Th1 and Th17 cells (217). Stimulus-induced production of $\mathrm{PGE}_{2}$ by a human mono-mac cell line in vitro may correlate with the tendency of vaccine adjuvants to induce fever in vivo (218). Overall, it is likely that elevated levels of $\mathrm{PGE}_{2}$ contribute to the acute-phase response as well as to the skewed polarization of T-helper cells in newborns.

\section{VITAMINS}

Vitamins, especially -A and -D, exert considerable influence on both innate and adaptive immune cell function $(6,103)$. Vitamin A enhances T-cell proliferation, likely by increasing IL-2 production (104) as well as DC maturation, antigen presentation, and migration (219). Vitamin A-deficient mice exhibit defects in helper T-cell activity (220). Serum vitamin A levels are influenced by diet and supplementation, but apparently only moderately by age (105).

Vitamin D3 is generated in the skin on exposure to sunlight or acquired in the diet from animal sources, fish in particular, whereas vitamin D2 is derived from plants. Both are utilized in supplementation, although vitamin D3 metabolites have higher affinities at human vitamin D binding proteins and receptors than vitamin D2 metabolites and therefore vitamin D3 may be considered preferable due to higher bioefficacy (221). Vitamin D3 suppresses lymphocyte function in vitro. The active vitamin D3 metabolite 1,25-dihydroxyvitamin D3 (1,25-(OH)2D3) 
inhibits T-cell proliferation $(106,107)$, production of IL-2 (107109), and the Th1-polarizing cytokine interferon- $\gamma$ (IFN $\gamma)$ (110, 111), while increasing production of the Th2 cytokine IL-4 (112). These effects are more pronounced in the effector T-cell subset that exhibits high expression of the vitamin D receptor (VDR) (113). Additionally, 1,25-(OH)2D3 impacts the capacity to activate Th1 T-cell responses by suppressing DC maturation and DC production of Th1-polarizing cytokine IL-12 (both the p35 and p40 subunits, thus preventing IL-12p70 and IL-12p40 assembly) but increasing the production of IL-10 $(114,115)$ which favors Treg differentiation $(116,117)$. The 1,25-(OH)2D3 also inhibits B-cell effector functions $(106,118)$, likely via 1,25-(OH)2D3 suppression of antigen-presenting cell function (119). The 1,25$(\mathrm{OH}) 2 \mathrm{D} 3$ stimulation of monocytes and macrophages, however, increases proliferation (120) and cathelicidin anti-microbial peptide production $(108,121)$, and activates the cellular process of autophagy (122), which can destroy intracellular bacteria, such as M. tuberculosis. Accordingly, vitamin D deficiency has been associated with increased risk of tuberculosis in several populations $(123,124)$, including children $(125,126)$. Circulating concentrations of vitamin D are heavily influenced by factors such as diet, supplementation, socioeconomic status, and season (127). Several studies have assessed the ontogeny of serum vitamin D levels. Cord serum levels of 1,25-dihydroxyvitamin $\mathrm{D}[1,25-(\mathrm{OH}) 2 \mathrm{D}]$ are moderately reduced but reach adult levels in neonatal peripheral blood by $24 \mathrm{~h}$ of age (formula feeding considered not likely to be the source of $1,25-(\mathrm{OH}) 2 \mathrm{D}$ in this study) (128). There are moderate increases in 1,25-(OH)2D during puberty in both sexes (129). In healthy subjects, 20-94 years of age neither serum 25-hydroxy- nor 1,25-dihydroxyvitamin D [25OHD and 1,25-(OH)2D] changes with age in either sex (130). While it is unclear what the impact of age is on circulating levels of vitamin D, it is clear that vitamin D levels play a critical role in neonatal and infant health, and that acquisition of vitamin D in these populations is amenable to supplementation and dietary modification (222). Vitamin D deficiency certainly needs to be combated, but it may also be true that supplementation could influence immune function by polarizing the adaptive immune response toward a Th2 profile, which should be a topic for future research.

Other vitamins and minerals, such as vitamins $\mathrm{C}$ and $\mathrm{E}, \mathrm{B}$ vitamins, and trace elements, can also impact immune function (223) and warrant consideration in populations with limited dietary access to these molecules.

\section{PURINES}

Plasma purine nucleotides and nucleosides, particularly adenosine triphosphate (ATP), adenosine diphosphate (ADP), and adenosine, are critical signaling molecules that regulate the function of a wide variety of cells, including immune cells. Extracellular ATP (eATP) influences T-cell activation $(224,225)$ and proliferation $(226,227)$, promotes neutrophil/endothelial cell adhesion (228), degranulation $(229,230)$, and reactive oxygen species (ROS) production (231), as well as other pro-inflammatory immune cell functions (232). eATP is transported to the extracellular space by vesicular trafficking, secreted via pannexin-1 channels (233), or released in large quantities from necrotic cells. Extracellular ADP (eADP) can be derived from eATP via dephosphorylation, and is also released into circulation from platelets following activation. eATP and eADP can stimulate P2 purinergic receptors and also serve as a source of adenosine (Ado) through dephosphorylation by several types of ecto-nucleotidases leading to adenosine receptor signaling (234). Extracellular adenosine (eAdo) has a nearly opposite profile of immune cell regulating effects from the precursor ATP: eAdo inhibits neutrophil-endothelial adhesion $(131,132)$ and effector functions (133-135), macrophage production of pro-inflammatory or Th1-polarizing cytokines (IL-12p70, TNF- $\alpha$ ) (232), and T-cell proliferation and effector functions $(136,137)$. By modulating the amount of adenosine, enzymes that metabolize extracellular purines, including several families of ecto-nucleotidases (235) and adenosine deaminase (ADA1), help regulate whether signaling is tilted toward a P2 receptormediated pro-inflammatory response, or a P1 receptor-mediated anti-inflammatory response. Cord blood plasma contains significantly higher levels of adenosine than adult peripheral blood plasma (138). In addition, the purine enzyme profile in cord blood plasma - elevated AMP dephosphorylating activity (alkaline phosphatase and soluble CD73) but lower adenosine deaminase activity compared to adults - favors generation of adenosine from purine nucleotides (152).

\section{CONCLUSION}

Blood plasma contains a complex mixture of bioactive molecules, including proteins, sugars, hormones, vitamins, and purines, many of which have influence on the host response to infection. The distinct molecular composition of blood plasma at birth and during the neonatal period contributes to distinct immunological function in newborns. A molecular milieu that blunts pro-inflammatory/Th1-polarizing responses likely serves to protect in utero against maternal adaptive non-self immune responses, and may help mediate the transition to the foreign antigen-rich ex utero environment. However, this polarization may come at a cost with respect to impaired host defense against intracellular pathogens. Such immune polarization and heightened susceptibility are especially evident in preterm neonates that have lower levels of maternal antibodies and certain complement proteins as compared to term subjects, leaving them particularly dependent on endogenous defense against infection. Of note, immunization of neonates with BCG modulates Ab production to both HBV and oral polio vaccination (OPV) (236), which, given the different routes of administration, suggests a role for soluble mediators induced by one vaccine impacting on the subsequent immune response to another. Cautious manipulation of the immunoregulatory capacity of neonatal blood plasma by targeting specific molecules and signaling pathways may optimize responses to infection and immunization.

\section{ACKNOWLEDGMENTS}

Ofer Levy's laboratory is supported by Global Health (OPPGH5284) and Grand Challenges Explorations (OPP1035192) awards from the Bill and Melinda Gates Foundation, NIH grant 1R01AI100135-01, and sponsored research agreements with 3M Drug Delivery Systems, Crucell, and MedImmune. Matthew Aaron Pettengill was supported by NIH Training Grant T32 HD055148. Simon Daniël van Haren is supported by a Thrasher Research Fund Early Career Award. 


\section{REFERENCES}

1. Cao Z, Yende S, Kellum JA, Robinson RA. Additions to the human plasma proteome via a tandem MARS depletion iTRAQ-based workflow. Int J Proteomics (2013) 2013:654356. doi:10.1155/2013/654356

2. Lawton KA, Berger A, Mitchell M, Milgram KE, Evans AM, Guo L, et al. Analysis of the adult human plasma metabolome. Pharmacogenomics (2008) 9(4):383-97. doi:10.2217/14622416.9.4.383

3. Belderbos ME, Levy O, Meyaard L, Bont L. Plasma-mediated immune suppression: a neonatal perspective. Pediatr Allergy Immunol (2013) 24(2):102-13. doi:10.1111/pai.12023

4. Hazlett L, Wu M. Defensins in innate immunity. Cell Tissue Res (2011) 343(1):175-88. doi:10.1007/s00441-010-1022-4

5. Mackey-Lawrence NM, Petri WA Jr. Leptin and mucosal immunity. Mucosal Immunol (2012) 5(5):472-9. doi:10.1038/mi.2012

6. Mora JR, Iwata M, von Andrian UH. Vitamin effects on the immune system: vitamins A and D take centre stage. Nat Rev Immunol (2008) 8(9):685-98. doi:10.1038/nri2378

7. Levy O. Innate immunity of the newborn: basic mechanisms and clinical correlates. Nat Rev Immunol (2007) 7(5):379-90. doi:10.1038/nri2075

8. Dowling DJ, Levy O. Ontogeny of early life immunity. Trends Immunol (2014) 35(7):299-310. doi:10.1016/j.it.2014.04.007

9. Rincon M, Anguita J, Nakamura T, Fikrig E, Flavell RA. Interleukin (IL)-6 directs the differentiation of IL-4-producing CD4+ T cells. J Exp Med (1997) 185(3):461-9. doi:10.1084/jem.185.3.461

10. Xing Z, Gauldie J, Cox G, Baumann H, Jordana M, Lei XF, et al. IL-6 is an antiinflammatory cytokine required for controlling local or systemic acute inflammatory responses. J Clin Invest (1998) 101(2):311-20. doi:10.1172/ JCI1368

11. Angelone DF, Wessels MR, Coughlin M, Suter EE, Valentini P, Kalish LA, et al. Innate immunity of the human newborn is polarized toward a high ratio of IL6/TNF-alpha production in vitro and in vivo. Pediatr Res (2006) 60(2):205-9. doi:10.1203/01.pdr.0000228319.10481.ea

12. Lavoie PM, Huang Q, Jolette E, Whalen M, Nuyt AM, Audibert F, et al. Profound lack of interleukin (IL)-12/IL-23p40 in neonates born early in gestation is associated with an increased risk of sepsis. J Infect Dis (2010) 202(11):1754-63. doi:10.1086/657143

13. Akdis CA, Akdis M. Mechanisms and treatment of allergic disease in the big picture of regulatory T cells. J Allergy Clin Immunol (2009) 123(4):735-46. doi:10.1016/j.jaci.2009.02.030

14. de Waal Malefyt R, Abrams J, Bennett B, Figdor CG, de Vries JE. Interleukin 10(IL-10) inhibits cytokine synthesis by human monocytes: an autoregulatory role of IL-10 produced by monocytes. J Exp Med (1991) 174(5):1209-20. doi:10.1084/jem.174.5.1209

15. Taylor A, Akdis M, Joss A, Akkoc T, Wenig R, Colonna M I, et al. IL-10 inhibits CD28 and ICOS costimulations of T cells via src homology 2 domaincontaining protein tyrosine phosphatase 1. J Allergy Clin Immunol (2007) 120(1):76-83. doi:10.1016/j.jaci.2007.04.004

16. Liu EM, Law HK, Lau YL. Mycobacterium bovis bacillus Calmette-Guerin treated human cord blood monocyte-derived dendritic cells polarize naive $\mathrm{T}$ cells into a tolerogenic phenotype in newborns. World J Pediatr (2010) 6(2):132-40. doi:10.1007/s12519-010-0019-0

17. Caron JE, La Pine TR, Augustine NH, Martins TB, Hill HR. Multiplex analysis of toll-like receptor-stimulated neonatal cytokine response. Neonatology (2010) 97(3):266-73. doi:10.1159/000255165

18. Yerkovich ST, Wikstrom ME, Suriyaarachchi D, Prescott SL, Upham JW, Holt PG. Postnatal development of monocyte cytokine responses to bacterial lipopolysaccharide. Pediatr Res (2007) 62(5):547-52. doi:10.1203/PDR. 0b013e3181568105

19. Akkoc T, Aydogan M, Yildiz A, Karakoc-Aydiner E, Eifan A, Keles S, et al. Neonatal BCG vaccination induces IL-10 production by CD4+ CD25+ T cells. Pediatr Allergy Immunol (2010) 21(7):1059-63. doi:10.1111/j.1399-3038.2010. 01051.x

20. Chelvarajan RL, Collins SM I, Doubinskaia E, Goes S, Van Willigen J, Flanagan D, et al. Defective macrophage function in neonates and its impact on unresponsiveness of neonates to polysaccharide antigens. J Leukoc Biol (2004) 75(6):982-94. doi:10.1189/jlb.0403179

21. Kobayashi M, Fitz L, Ryan M, Hewick RM, Clark SC, Chan S, et al. Identification and purification of natural killer cell stimulatory factor (NKSF), a cytokine with multiple biologic effects on human lymphocytes. J Exp Med (1989) 170(3):827-45. doi:10.1084/jem.170.3.827
22. Barton GM, Medzhitov R. Control of adaptive immune responses by Tolllike receptors. Curr Opin Immunol (2002) 14(3):380-3. doi:10.1016/S09527915(02)00343-6

23. Carreno BM, Becker-Hapak M, Huang A, Chan M, Alyasiry A, Lie WR, et al. IL-12p70-producing patient DC vaccine elicits Tc1-polarized immunity. J Clin Invest (2013) 123(8):3383-94. doi:10.1172/JCI68395

24. Burl S, Townend J, Njie-Jobe J, Cox M, Adetifa UJ, Touray E, et al. Agedependent maturation of toll-like receptor-mediated cytokine responses in Gambian infants. PLoS One (2011) 6(4):e18185. doi:10.1371/journal.pone. 0018185

25. Levy O, Zarember KA, Roy RM, Cywes C, Godowski PJ, Wessels MR. Selective impairment of TLR-mediated innate immunity in human newborns: neonatal blood plasma reduces monocyte TNF-alpha induction by bacterial lipopeptides, lipopolysaccharide, and imiquimod, but preserves the response to R-848. J Immunol (2004) 173(7):4627-34. doi:10.4049/jimmunol.173.7.4627

26. van den Biggelaar AH, Richmond PC, Pomat WS, Phuanukoonnon S, NadalSims MA, Devitt CJ, et al. Neonatal pneumococcal conjugate vaccine immunization primes $\mathrm{T}$ cells for preferential Th2 cytokine expression: a randomized controlled trial in Papua new Guinea. Vaccine (2009) 27(9):1340-7. doi:10.1016/j.vaccine.2008.12.046

27. Saito S, Kato Y, Maruyama M, Ichijo M. A study of interferon-gamma and interleukin-2 production in premature neonates and neonates with intrauterine growth retardation. Am J Reprod Immunol (1992) 27(1-2):63-8. doi:10. 1111/j.1600-0897.1992.tb00725.x

28. Levy O, Suter EE, Miller RL, Wessels MR. Unique efficacy of Toll-like receptor 8 agonists in activating human neonatal antigen-presenting cells. Blood (2006) 108(4):1284-90. doi:10.1182/blood-2005-12-4821

29. Basinski TM, Holzmann D, Eiwegger T, Zimmermann M, Klunker S, Meyer $\mathrm{N}$, et al. Dual nature of $\mathrm{T}$ cell-epithelium interaction in chronic rhinosinusitis. J Allergy Clin Immunol (2009) 124(1):e1-8. doi:10.1016/j.jaci.2009

30. Zimmermann M, Koreck A, Meyer N, Basinski T, Meiler F, Simone B, et al. TNF-like weak inducer of apoptosis (TWEAK) and TNF-alpha cooperate in the induction of keratinocyte apoptosis. J Allergy Clin Immunol (2011) 127(1):e1-10. doi:10.1016/j.jaci.2010

31. Purkerson J, Isakson P. A two-signal model for regulation of immunoglobulin isotype switching. FASEB J (1992) 6(14):3245-52.

32. Zhou F. Molecular mechanisms of IFN-gamma to up-regulate MHC class I antigen processing and presentation. Int Rev Immunol (2009) 28(3-4):239-60. doi:10.1080/08830180902978120

33. Vekemans J, Ota MO, Wang EC, Kidd M, Borysiewicz LK, Whittle H, et al. $\mathrm{T}$ cell responses to vaccines in infants: defective IFNgamma production after oral polio vaccination. Clin Exp Immunol (2002) 127(3):495-8. doi:10.1046/j. 1365-2249.2002.01788.x

34. Ota MO, Vekemans J, Schlegel-Haueter SE, Fielding K, Whittle H, Lambert $\mathrm{PH}$, et al. Hepatitis B immunisation induces higher antibody and memory Th2 responses in new-borns than in adults. Vaccine (2004) 22(3-4):511-9. doi:10.1016/j.vaccine.2003.07.020

35. PrabhuDas M, Adkins B, Gans H, King C, Levy O, Ramilo O, et al. Challenges in infant immunity: implications for responses to infection and vaccines. Nat Immunol (2011) 12(3):189-94. doi:10.1038/ni0311-189

36. Wolf AM, Wolf D, Rumpold H, Enrich B, Tilg H. Adiponectin induces the anti-inflammatory cytokines IL-10 and IL-1RA in human leukocytes. Biochem Biophys Res Commun (2004) 323(2):630-5. doi:10.1016/j.bbrc.2004.08.145

37. Wilk S, Scheibenbogen C, Bauer S, Jenke A, Rother M, Guerreiro M, et al. Adiponectin is a negative regulator of antigen-activated T cells. Eur J Immunol (2011) 41(8):2323-32. doi:10.1002/eji.201041349

38. Tsang JY, Li D, Ho D, Peng J, Xu A, Lamb J, et al. Novel immunomodulatory effects of adiponectin on dendritic cell functions. Int Immunopharmacol (2011) 11(5):604-9. doi:10.1016/j.intimp.2010.11.009

39. Kyriakakou M, Malamitsi-Puchner A, Militsi H, Boutsikou T, Margeli A, Hassiakos D, et al. Leptin and adiponectin concentrations in intrauterine growth restricted and appropriate for gestational age fetuses, neonates, and their mothers. Eur J Endocrinol (2008) 158(3):343-8. doi:10.1530/EJE-07-0692

40. Cangemi G, Di Iorgi N, Barco S, Reggiardo G, Maghnie M, Melioli G. Plasma total adiponectin levels in pediatrics: reference intervals calculated as a continuous variable of age. Clin Biochem (2012) 45(18):1703-5. doi:10.1016/ j.clinbiochem.2012.08.001

41. Weyermann M, Beermann C, Brenner H, Rothenbacher D. Adiponectin and leptin in maternal serum, cord blood, and breast milk. Clin Chem (2006) 52(11):2095-102. doi:10.1373/clinchem.2006.071019 
42. McLatchie LM, Fraser NJ, Main MJ, Wise A, Brown J, Thompson N, et al. RAMPs regulate the transport and ligand specificity of the calcitonin-receptorlike receptor. Nature (1998) 393(6683):333-9. doi:10.1038/30666

43. Zudaire E, Portal-Nunez S, Cuttitta F. The central role of adrenomedullin in host defense. J Leukoc Biol (2006) 80(2):237-44. doi:10.1189/jlb.0206123

44. Allaker RP, Zihni C, Kapas S. An investigation into the antimicrobial effects of adrenomedullin on members of the skin, oral, respiratory tract and gut microflora. FEMS Immunol Med Microbiol (1999) 23(4):289-93. doi:10.1016/ S0928-8244(98)00148-5

45. Gonzalez-Rey E, Chorny A, Varela N, Robledo G, Delgado M. Urocortin and adrenomedullin prevent lethal endotoxemia by down-regulating the inflammatory response. Am J Pathol (2006) 168(6):1921-30. doi:10.2353/ajpath.2006. 051104

46. Di Iorio R, Marinoni E, Scavo D, Letizia C, Cosmi EV. Adrenomedullin in pregnancy. Lancet (1997) 349(9048):328. doi:10.1016/S0140-6736(05)62827-9

47. Farooqi IS, Matarese G, Lord GM, Keogh JM, Lawrence E, Agwu C, et al. Beneficial effects of leptin on obesity, $\mathrm{T}$ cell hyporesponsiveness, and neuroendocrine/metabolic dysfunction of human congenital leptin deficiency. J Clin Invest (2002) 110(8):1093-103. doi:10.1172/JCI15693

48. Farooqi IS, Wangensteen T, Collins S, Kimber W, Matarese G, Keogh JM, et al. Clinical and molecular genetic spectrum of congenital deficiency of the leptin receptor. N Engl J Med (2007) 356(3):237-47. doi:10.1056/NEJMoa063988

49. Gibson WT, Farooqi IS, Moreau M, DePaoli AM, Lawrence E, O’Rahilly S, et al. Congenital leptin deficiency due to homozygosity for the Delta133G mutation: report of another case and evaluation of response to four years of leptin therapy. J Clin Endocrinol Metab (2004) 89(10):4821-6. doi:10.1210/jc.20040376

50. Lemos MP, Rhee KY, McKinney JD. Expression of the leptin receptor outside of bone marrow-derived cells regulates tuberculosis control and lung macrophage MHC expression. J Immunol (2011) 187(7):3776-84. doi:10.4049/jimmunol. 1003226

51. Moore SI, Huffnagle GB, Chen GH, White ES, Mancuso P. Leptin modulates neutrophil phagocytosis of Klebsiella pneumoniae. Infect Immun (2003) 71(7):4182-5. doi:10.1128/IAI.71.7.4182-4185.2003

52. Hsu A, Aronoff DM, Phipps J, Goel D, Mancuso P. Leptin improves pulmonary bacterial clearance and survival in ob/ob mice during pneumococcal pneumonia. Clin Exp Immunol (2007) 150(2):332-9. doi:10.1111/j.1365-2249.2007. 03491.x

53. Mancuso P, Huffnagle GB, Olszewski MA, Phipps J, Peters-Golden M. Leptin corrects host defense defects after acute starvation in murine pneumococcal pneumonia. Am J Respir Crit Care Med (2006) 173(2):212-8. doi:10.1164/rccm.200506-909OC

54. Mancuso P, Peters-Golden M, Goel D, Goldberg J, Brock TG, Greenwald-Yarnell $M$, et al. Disruption of leptin receptor-STAT3 signaling enhances leukotriene production and pulmonary host defense against pneumococcal pneumonia. J Immunol (2011) 186(2):1081-90. doi:10.4049/jimmunol.1001470

55. Mouzaki A, Panagoulias I, Raptis G, Farri-Kostopoulou E. Cord blood leptin levels of healthy neonates are associated with IFN-gamma production by cord blood T-cells. PLoS One (2012) 7(7):e40830. doi:10.1371/journal.pone. 0040830

56. Bellone S, Rapa A, Petri A, Zavallone A, Strigini L, Chiorboli E, et al. Leptin levels as function of age, gender, auxological and hormonal parameters in 202 healthy neonates at birth and during the first month of life. J Endocrinol Invest (2004) 27(1):18-23. doi:10.1007/BF03350905

57. Mann DR, Johnson AO, Gimpel T, Castracane VD. Changes in circulating leptin, leptin receptor, and gonadal hormones from infancy until advanced age in humans. J Clin Endocrinol Metab (2003) 88(7):3339-45. doi:10.1210/jc.2002022030

58. Ricklin D, Hajishengallis G, Yang K, Lambris JD. Complement: a key system for immune surveillance and homeostasis. Nat Immunol (2010) 11(9):785-97. doi:10.1038/ni.1923

59. Wolach B, Dolfin T, Regev R, Gilboa S, Schlesinger M. The development of the complement system after 28 weeks' gestation. Acta Paediatr (1997) 86(5):523-7. doi:10.1111/j.1651-2227.1997.tb08924.x

60. McGreal EP, Hearne K, Spiller OB. Off to a slow start: under-development of the complement system in term newborns is more substantial following premature birth. Immunobiology (2012) 217(2):176-86. doi:10.1016/j.imbio. 2011.07.027
61. Davis CA, Vallota EH, Forristal J. Serum complement levels in infancy: age related changes. Pediatr Res (1979) 13(9):1043-6. doi:10.1203/00006450197909000-00019

62. Super M, Thiel S, Lu J, Levinsky RJ, Turner MW. Association of low levels of mannan-binding protein with a common defect of opsonisation. Lancet (1989) 2(8674):1236-9. doi:10.1016/S0140-6736(89)91849-7

63. Turner MW. The role of mannose-binding lectin in health and disease. $\mathrm{Mol}$ Immunol (2003) 40(7):423-9. doi:10.1016/S0161-5890(03)00155-X

64. Garnacho-Montero J, Garcia-Cabrera E, Jimenez-Alvarez R, Diaz-Martin A, Revuelto-Rey J, Aznar-Martin J, et al. Genetic variants of the MBL2 gene are associated with mortality in pneumococcal sepsis. Diagn Microbiol Infect Dis (2012) 73(1):39-44. doi:10.1016/j.diagmicrobio.2012.02.002

65. Garred P, Strom J, Quist L, Taaning E, Madsen HO. Association of mannose-binding lectin polymorphisms with sepsis and fatal outcome, in patients with systemic inflammatory response syndrome. J Infect Dis (2003) 188(9):1394-403. doi:10.1086/379044

66. de Benedetti F, Auriti C, D’Urbano LE, Ronchetti MP, Rava L, Tozzi A, et al. Low serum levels of mannose binding lectin are a risk factor for neonatal sepsis. Pediatr Res (2007) 61(3):325-8. doi:10.1203/pdr.0b013e318030d12f

67. Hilgendorff A, Schmidt R, Bohnert A, Merz C, Bein G, Gortner L. Host defence lectins in preterm neonates. Acta Paediatr (2005) 94(6):794-9. doi:10.1080/ 08035250410027363

68. Sallenbach S, Thiel S, Aebi C, Otth M, Bigler S, Jensenius JC, et al. Serum concentrations of lectin-pathway components in healthy neonates, children and adults: mannan-binding lectin (MBL), M-, L-, and H-ficolin, and MBL-associated serine protease-2 (MASP-2). Pediatr Allergy Immunol (2011) 22(4):424-30. doi:10.1111/j.1399-3038.2010.01104.x

69. Swierzko AS, Szala A, Cedzynski M, Domzalska-Popadiuk I, Borkowska-Klos M, Jopek A, et al. Mannan-binding lectin genotypes and genotype-phenotype relationships in a large cohort of polish neonates. Hum Immunol (2009) 70(1):68-72. doi:10.1016/j.humimm.2008.10.004

70. Swierzko AS, Atkinson AP, Cedzynski M, Macdonald SL, Szala A, DomzalskaPopadiuk I, et al. Two factors of the lectin pathway of complement, L-ficolin and mannan-binding lectin, and their associations with prematurity, low birthweight and infections in a large cohort of Polish neonates. Mol Immunol (2009) 46(4):551-8. doi:10.1016/j.molimm.2008.07.025

71. Wolach B, Carmi D, Gilboa S, Satar M, Segal S, Dolfin T, et al. Some aspects of the humoral immunity and the phagocytic function in newborn infants. Isr J Med Sci (1994) 30(5-6):331-5.

72. Johnson U, Truedsson L, Gustavii B. Complement components in 100 newborns and their mothers determined by electroimmunoassay. Acta Pathol Microbiol Immunol Scand C (1983) 91(2):147-50.

73. Adinolfi M, Dobson NC, Bradwell AR. Synthesis of two components of human complement, beta $1 \mathrm{H}$ and C3bINA, during fetal life. Acta Paediatr Scand (1981) 70(5):705-10. doi:10.1111/j.1651-2227.1981.tb05772.x

74. Hogasen AK I, Overlie I, Hansen TW, Abrahamsen TG, Finne PH, Hogasen $\mathrm{K}$. The analysis of the complement activation product SC5 b-9 is applicable in neonates in spite of their profound C9 deficiency. J Perinat Med (2000) 28(1):39-48. doi:10.1515/JPM.2000.006

75. Miyano A, Miyamichi T, Nakayama M, Kitajima H, Shimizu A. Effect of chorioamnionitis on the levels of serum proteins in the cord blood of premature infants. Arch Pathol Lab Med (1996) 120(3):245-8.

76. Ueda H, Nakanishi A, Ichijo M. Immunochemical quantitation of serum complement components in SFD and AFD infants. Tohoku J Exp Med (1980) 132(1):111-6. doi:10.1620/tjem.132.111

77. Legrand D. Lactoferrin, a key molecule in immune and inflammatory processes. Biochem Cell Biol (2012) 90(3):252-68. doi:10.1139/o11-056

78. Ambruso DR, Bentwood B, Henson PM, Johnston RB Jr. Oxidative metabolism of cord blood neutrophils: relationship to content and degranulation of cytoplasmic granules. Pediatr Res (1984) 18(11):1148-53. doi:10.1203/00006450198411000-00019

79. Scott PH. Plasma lactoferrin levels in newborn preterm infants: effect of infection. Ann Clin Biochem (1989) 26(Pt 5):412-5. doi:10.1177/ 000456328902600506

80. Balakrishnan A, Marathe SA, Joglekar M, Chakravortty D. Bacterici$\mathrm{dal} /$ permeability increasing protein: a multifaceted protein with functions beyond LPS neutralization. Innate Immun (2013) 19(4):339-47. doi:10.1177/ 1753425912465098 
81. Levy O, Martin S, Eichenwald E, Ganz T, Valore E, Carroll SF, et al. Impaired innate immunity in the newborn: newborn neutrophils are deficient in bactericidal/permeability-increasing protein. Pediatrics (1999) 104(6):1327-33. doi:10.1542/peds.104.6.1327

82. Nupponen I, Turunen R, Nevalainen T, Peuravuori H, Pohjavuori M, Repo $\mathrm{H}$, et al. Extracellular release of bactericidal/permeability-increasing protein in newborn infants. Pediatr Res (2002) 51(6):670-4. doi:10.1203/00006450200206000-00002

83. Gombart AF, Borregaard N, Koeffler HP. Human cathelicidin antimicrobial peptide (CAMP) gene is a direct target of the vitamin D receptor and is strongly up-regulated in myeloid cells by 1,25-dihydroxyvitamin D3. FASEB J (2005) 19(9):1067-77. doi:10.1096/fj.04-3284com

84. Mandic Havelka A, Yektaei-Karin E, Hultenby K, Sorensen OE, Lundahl J, Berggren V, et al. Maternal plasma level of antimicrobial peptide LL37 is a major determinant factor of neonatal plasma LL37 level. Acta Paediatr (2010) 99(6):836-41. doi:10.1111/j.1651-2227.2010.01726.x

85. Wilson SS, Wiens ME, Smith JG. Antiviral mechanisms of human defensins. $J$ Mol Biol (2013) 425(24):4965-80. doi:10.1016/j.jmb.2013.09.038

86. Yount NY, Yeaman MR. Peptide antimicrobials: cell wall as a bacterial target. Ann N Y Acad Sci (2013) 1277:127-38. doi:10.1111/nyas.12005

87. Aerts AM, Francois IE, Cammue BP, Thevissen K. The mode of antifungal action of plant, insect and human defensins. Cell Mol Life Sci (2008) 65(13):2069-79. doi:10.1007/s00018-008-8035-0

88. Olbrich P, Pavon A, Rosso ML, Molinos A, de Felipe B, Sanchez B, et al. Association of human beta-defensin-2 serum levels and sepsis in preterm neonates*. Pediatr Crit Care Med (2013) 14(8):796-800. doi:10.1097/PCC. 0b013e3182975e0f

89. Spiegelberg HL. Biological role of different antibody classes. Int Arch Allergy Appl Immunol (1989) 90(Suppl 1):22-7. doi:10.1159/000235071

90. Nimmerjahn F, Ravetch JV. Fc-receptors as regulators of immunity. $A d v$ Immunol (2007) 96:179-204. doi:10.1016/S0065-2776(07)96005-8

91. Jolliff CR, Cost KM, Stivrins PC, Grossman PP, Nolte CR, Franco SM, et al. Reference intervals for serum IgG, IgA, IgM, C3, and C4 as determined by rate nephelometry. Clin Chem (1982) 28(1):126-8.

92. Nagasaka H, Chiba H, Kikuta H, Akita H, Takahashi Y, Yanai H, et al. Unique character and metabolism of high density lipoprotein (HDL) in fetus. Atherosclerosis (2002) 161(1):215-23. doi:10.1016/S0021-9150(01) 00663-3

93. Sreckovic I, Birner-Gruenberger R, Obrist B, Stojakovic T, Scharnagl H, Holzer $\mathrm{M}$, et al. Distinct composition of human fetal HDL attenuates its anti-oxidative capacity. Biochim Biophys Acta (2013) 1831(4):737-46. doi:10.1016/j.bbalip. 2012.12.015

94. Augsten M, Hackl H, Ebner B, Chemelli A, Glatter O, Marsche G, et al. Fetal HDL/apoE: a novel regulator of gene expression in human placental endothelial cells. Physiol Genomics (2011) 43(22):1255-62. doi:10.1152/physiolgenomics. 00109.2011

95. Ginsburg BE, Zetterstrom R. Serum cholesterol concentrations in newborn infants with gestational ages of 28-42 weeks. Acta Paediatr Scand (1980) 69(5):587-92. doi:10.1111/j.1651-2227.1980.tb07326.x

96. Venza I, Giordano L, Piraino G, Medici N, Ceci G, Teti D. Prostaglandin E2 signalling pathway in human $\mathrm{T}$ lymphocytes from healthy and conjunctiva basal cell carcinoma-bearing subjects. Immunol Cell Biol (2001) 79(5):482-9. doi:10.1046/j.1440-1711.2001.01034.x

97. Yen JH, Kocieda VP, Jing H, Ganea D. Prostaglandin E2 induces matrix metalloproteinase 9 expression in dendritic cells through two independent signaling pathways leading to activator protein 1 (AP-1) activation. J Biol Chem (2011) 286(45):38913-23. doi:10.1074/jbc.M111.252932

98. Kalinski P. Regulation of immune responses by prostaglandin E2. J Immunol (2012) 188(1):21-8. doi:10.4049/jimmunol.1101029

99. Scandella E, Men Y, Gillessen S, Forster R, Groettrup M. Prostaglandin E2 is a key factor for CCR7 surface expression and migration of monocytederived dendritic cells. Blood (2002) 100(4):1354-61. doi:10.1182/blood2001-11-0017

100. van Helden SF, Oud MM, Joosten B, Peterse N, Figdor CG, van Leeuwen FN. PGE2-mediated podosome loss in dendritic cells is dependent on actomyosin contraction downstream of the RhoA-Rho-kinase axis. J Cell Sci (2008) 121(Pt 7):1096-106. doi:10.1242/jcs.020289

101. Kalinski P, Vieira PL, Schuitemaker JH, de Jong EC, Kapsenberg ML. Prostaglandin $\mathrm{E}(2)$ is a selective inducer of interleukin-12 p40 (IL-12p40) production and an inhibitor of bioactive IL-12p70 heterodimer. Blood (2001) 97(11):3466-9. doi:10.1182/blood.V97.11.3466

102. Belderbos ME, Levy O, Stalpers F, Kimpen JL, Meyaard L, Bont L. Neonatal plasma polarizes TLR4-mediated cytokine responses towards low IL-12p70 and high IL-10 production via distinct factors. PLoS One (2012) 7(3):e33419. doi:10.1371/journal.pone.0033419

103. Wintergerst ES, Maggini S, Hornig DH. Contribution of selected vitamins and trace elements to immune function. Ann Nutr Metab (2007) 51(4):301-23. doi: $10.1159 / 000107673$

104. Ertesvag A, Engedal N, Naderi S, Blomhoff HK. Retinoic acid stimulates the cell cycle machinery in normal T cells: involvement of retinoic acid receptormediated IL-2 secretion. J Immunol (2002) 169(10):5555-63. doi:10.4049/ jimmunol.169.10.5555

105. Raizman JE, Cohen AH, Teodoro-Morrison T, Wan B, Khun-Chen M, Wilkenson $\mathrm{C}$, et al. Pediatric reference value distributions for vitamins $\mathrm{A}$ and $\mathrm{E}$ in the CALIPER cohort and establishment of age-stratified reference intervals. Clin Biochem (2014) 47(9):812-5. doi:10.1016/j.clinbiochem.2014.03.025

106. Lemire JM, Adams JS, Sakai R, Jordan SC. 1 Alpha,25-dihydroxyvitamin D3 suppresses proliferation and immunoglobulin production by normal human peripheral blood mononuclear cells. J Clin Invest (1984) 74(2):657-61. doi:10.1172/JCI111465

107. Rigby WF, Stacy T, Fanger MW. Inhibition of T lymphocyte mitogenesis by 1,25-dihydroxyvitamin D3 (calcitriol). J Clin Invest (1984) 74(4):1451-5. doi:10.1172/JCI111557

108. Bhalla AK, Amento EP, Krane SM. Differential effects of 1,25-dihydroxyvitamin D3 on human lymphocytes and monocyte/macrophages: inhibition of interleukin-2 and augmentation of interleukin-1 production. Cell Immunol (1986) 98(2):311-22. doi:10.1016/0008-8749(86)90291-1

109. Lemire JM, A JS, Kermani-Arab V, Bakke AC, Sakai R, Jordan SC. dams. J Immunol (1985) 134(5):3032-5.

110. Reichel H, Koeffler HP, Tobler A, Norman AW. 1 alpha,25-Dihydroxyvitamin D3 inhibits gamma-interferon synthesis by normal human peripheral blood lymphocytes. Proc Natl Acad Sci USA (1987) 84(10):3385-9. doi:10.1073/pnas. 84.10.3385

111. Rigby WF, Yirinec B, Oldershaw RL, Fanger MW. Comparison of the effects of 1,25-dihydroxyvitamin D3 on T lymphocyte subpopulations. Eur J Immunol (1987) 17(4):563-6. doi:10.1002/eji.1830170420

112. van Etten E, Mathieu C. Immunoregulation by 1,25-dihydroxyvitamin D3: basic concepts. J Steroid Biochem Mol Biol (2005) 97(1-2):93-101. doi:10.1016/ j.jsbmb.2005.06.002

113. Veldman CM, Cantorna MT, DeLuca HF. Expression of 1,25-dihydroxyvitamin $\mathrm{D}(3)$ receptor in the immune system. Arch Biochem Biophys (2000) 374(2):334-8. doi:10.1006/abbi.1999.1605

114. D’Ambrosio D, Cippitelli M, Cocciolo MG, Mazzeo D, Di Lucia P, Lang R, et al. Inhibition of IL-12 production by 1,25-dihydroxyvitamin D3. Involvement of NF-kappaB downregulation in transcriptional repression of the p40 gene. J Clin Invest (1998) 101(1):252-62. doi:10.1172/JCI1050

115. Penna G, Adorini L. 1 Alpha,25-dihydroxyvitamin D3 inhibits differentiation, maturation, activation, and survival of dendritic cells leading to impaired alloreactive T cell activation. J Immunol (2000) 164(5):2405-11. doi:10.4049/ jimmunol.164.5.2405

116. Gorman S, Kuritzky LA, Judge MA, Dixon KM, McGlade JP, Mason RS, et al. Topically applied 1,25-dihydroxyvitamin D3 enhances the suppressive activity of CD4+CD25+ cells in the draining lymph nodes. J Immunol (2007) 179(9):6273-83. doi:10.4049/jimmunol.179.9.6273

117. Penna G, Roncari A, Amuchastegui S, Daniel KC, Berti E, Colonna M, et al. Expression of the inhibitory receptor ILT3 on dendritic cells is dispensable for induction of CD4+Foxp3+ regulatory $\mathrm{T}$ cells by 1,25-dihydroxyvitamin D3. Blood (2005) 106(10):3490-7. doi:10.1182/blood-2005-05-2044

118. Chen S, Sims GP, Chen XX, Gu YY, Lipsky PE. Modulatory effects of 1,25dihydroxyvitamin D3 on human B cell differentiation. J Immunol (2007) 179(3):1634-47. doi:10.4049/jimmunol.179.3.1634

119. Muller K, Heilmann C, Poulsen LK, Barington T, Bendtzen K. The role of monocytes and $\mathrm{T}$ cells in 1,25-dihydroxyvitamin $\mathrm{D} 3$ mediated inhibition of $\mathrm{B}$ cell function in vitro. Immunopharmacology (1991) 21(2):121-8. doi:10.1016/ 0162-3109(91)90015-Q

120. Ohta M, Okabe T, Ozawa K, Urabe A, Takaku F. 1 alpha,25-dihydroxy vitamin D3 (calcitriol) stimulates proliferation of human circulating monocytes in vitro. FEBS Lett (1985) 185(1):9-13. doi:10.1016/0014-5793(85)80730-4 
121. Holick MF. Vitamin D deficiency. N Engl J Med (2007) 357(3):266-81. doi:10.1056/NEJMra070553

122. Jo EK. Innate immunity to mycobacteria: vitamin D and autophagy. Cell Microbiol (2010) 12(8):1026-35. doi:10.1111/j.1462-5822.2010.01491.x

123. Gibney KB, MacGregor L, Leder K, Torresi J, Marshall C, Ebeling PR, et al. Vitamin $\mathrm{D}$ deficiency is associated with tuberculosis and latent tuberculosis infection in immigrants from sub-Saharan Africa. Clin Infect Dis (2008) 46(3):443-6. doi:10.1086/525268

124. Nnoaham KE, Clarke A. Low serum vitamin D levels and tuberculosis: a systematic review and meta-analysis. Int J Epidemiol (2008) 37(1):113-9. doi:10.1093/ije/dym247

125. Gray K, Wood N, Gunasekera H, Sheikh M, Hazelton B, Barzi F, et al. Vitamin $\mathrm{d}$ and tuberculosis status in refugee children. Pediatr Infect Dis J (2012) 31(5):521-3. doi:10.1097/INF.0b013e3182456c55

126. Williams B, Williams AJ, Anderson ST. Vitamin D deficiency and insufficiency in children with tuberculosis. Pediatr Infect Dis J (2008) 27(10):941-2. doi:10.1097/INF.0b013e31817525df

127. Hilger J, Friedel A, Herr R, Rausch T, Roos F, Wahl DA, et al. A systematic review of vitamin D status in populations worldwide. Br J Nutr (2014) 111(1):23-45. doi:10.1017/S0007114513001840

128. Steichen JJ, Tsang RC, Gratton TL, Hamstra A, DeLuca HF. Vitamin D homeostasis in the perinatal period: 1,25-dihydroxyvitamin D in maternal, cord, and neonatal blood. N Engl J Med (1980) 302(6):315-9. doi:10.1056/ NEJM198002073020603

129. Aksnes L, Aarskog D. Plasma concentrations of vitamin D metabolites in puberty: effect of sexual maturation and implications for growth. J Clin Endocrinol Metab (1982) 55(1):94-101. doi:10.1210/jcem-55-1-94

130. Sherman SS, Hollis BW, Tobin JD. Vitamin D status and related parameters in a healthy population: the effects of age, sex, and season. J Clin Endocrinol Metab (1990) 71(2):405-13. doi:10.1210/jcem-71-2-405

131. Cronstein BN, Levin RI, Belanoff J, Weissmann G, Hirschhorn R. Adenosine: an endogenous inhibitor of neutrophil-mediated injury to endothelial cells. J Clin Invest (1986) 78(3):760-70. doi:10.1172/JCI112638

132. Eltzschig HK, Thompson LF, Karhausen J, Cotta RJ, Ibla JC, Robson SC, et al. Endogenous adenosine produced during hypoxia attenuates neutrophil accumulation: coordination by extracellular nucleotide metabolism. Blood (2004) 104(13):3986-92. doi:10.1182/blood-2004-06-2066

133. Bouma MG, Jeunhomme TM, Boyle DL, Dentener MA, Voitenok NN, van den Wildenberg FA, et al. Adenosine inhibits neutrophil degranulation in activated human whole blood: involvement of adenosine A2 and A3 receptors. JImmunol (1997) 158(11):5400-8.

134. Cronstein BN, Kramer SB, Weissmann G, Hirschhorn R. Adenosine: a physiological modulator of superoxide anion generation by human neutrophils. J Exp Med (1983) 158(4):1160-77. doi:10.1084/jem.158.4.1160

135. Cronstein BN, Rosenstein ED, Kramer SB, Weissmann G, Hirschhorn R. Adenosine; a physiologic modulator of superoxide anion generation by human neutrophils. Adenosine acts via an A2 receptor on human neutrophils. J Immunol (1985) 135(2):1366-71.

136. Csoka B, Himer L, Selmeczy Z, Vizi ES, Pacher P, Ledent C, et al. Adenosine A2A receptor activation inhibits $\mathrm{T}$ helper 1 and $\mathrm{T}$ helper 2 cell development and effector function. FASEB J (2008) 22(10):3491-9. doi:10. 1096/fj.08-107458

137. Sitkovsky MV, Ohta A. The 'danger' sensors that STOP the immune response: the A2 adenosine receptors? Trends Immunol (2005) 26(6):299-304. doi:10. 1016/j.it.2005.04.004

138. Levy O, Coughlin M, Cronstein BN, Roy RM, Desai A, Wessels MR. The adenosine system selectively inhibits TLR-mediated TNF-alpha production in the human newborn. J Immunol (2006) 177(3):1956-66. doi:10.4049/jimmunol. 177.3.1956

139. Zaghouani H, Hoeman CM, Adkins B. Neonatal immunity: faulty T-helpers and the shortcomings of dendritic cells. Trends Immunol (2009) 30(12):585-91. doi:10.1016/j.it.2009.09.002

140. Volpe E, Servant N, Zollinger R, Bogiatzi SI, Hupe P, Barillot E, et al. A critical function for transforming growth factor-beta, interleukin 23 and proinflammatory cytokines in driving and modulating human $\mathrm{T}(\mathrm{H})-17$ responses. Nat Immunol (2008) 9(6):650-7. doi:10.1038/ni.1613

141. Ulevitch RJ, Tobias PS. Recognition of gram-negative bacteria and endotoxin by the innate immune system. Curr Opin Immunol (1999) 11(1):19-22. doi:10.1016/S0952-7915(99)80004-1
142. Jones SA. Directing transition from innate to acquired immunity: defining a role for IL-6. J Immunol (2005) 175(6):3463-8. doi:10.4049/jimmunol.175.6. 3463

143. Vekemans J, Amedei A, Ota MO, D’Elios MM, Goetghebuer T, Ismaili J, et al. Neonatal bacillus Calmette-Guerin vaccination induces adult-like IFN-gamma production by CD4+ T lymphocytes. Eur J Immunol (2001) 31(5):1531-5. doi:10.1002/1521-4141(200105)31:5<1531::AID-IMMU1531>3.0.CO;2-1

144. Kollmann TR, Crabtree J, Rein-Weston A, Blimkie D, Thommai F, Wang XY, et al. Neonatal innate TLR-mediated responses are distinct from those of adults. J Immunol (2009) 183(11):7150-60. doi:10.4049/jimmunol.0901481

145. De Wit D, Tonon S, Olislagers V, Goriely S, Boutriaux M, Goldman M, et al. Impaired responses to toll-like receptor 4 and toll-like receptor 3 ligands in human cord blood. JAutoimmun (2003) 21(3):277-81. doi:10.1016/j.jaut.2003. 08.003

146. Philbin VJ, Dowling DJ, Gallington LC, Cortes G, Tan Z, Suter EE, et al. Imidazoquinoline Toll-like receptor 8 agonists activate human newborn monocytes and dendritic cells through adenosine-refractory and caspase-1-dependent pathways. J Allergy Clin Immunol (2012) 130(1):195-204e9. doi:10.1016/j.jaci. 2012.02.042

147. Dowling DJ, Tan Z, Prokopowicz ZM, Palmer CD, Matthews MA, Dietsch GN, et al. The ultra-potent and selective TLR8 agonist VTX-294 activates human newborn and adult leukocytes. PLoS One (2013) 8(3):e58164. doi:10.1371/ journal.pone.0058164

148. Dinarello CA. Immunological and inflammatory functions of the interleukin-1 family. Annu Rev Immunol (2009) 27:519-50. doi:10.1146/annurev.immunol. 021908.132612

149. Chung Y, Chang SH, Martinez GJ, Yang XO, Nurieva R, Kang HS, et al. Critical regulation of early Th17 cell differentiation by interleukin-1 signaling. Immunity (2009) 30(4):576-87. doi:10.1016/j.immuni.2009.02.007

150. Goriely S, Van Lint C, Dadkhah R, Libin M, De Wit D, Demonte D, et al. A defect in nucleosome remodeling prevents IL-12(p35) gene transcription in neonatal dendritic cells. J Exp Med (2004) 199(7):1011-6. doi:10.1084/jem. 20031272

151. Renneson J, Dutta B, Goriely S, Danis B, Lecomte S, Laes JF, et al. IL-12 and type I IFN response of neonatal myeloid DC to human CMV infection. Eur Immunol (2009) 39(10):2789-99. doi:10.1002/eji.200939414

152. Pettengill M, Robson S, Tresenriter M, Millan JL, Usheva A, Bingham T, et al. Soluble ecto-5'-nucleotidase (5'-NT), alkaline phosphatase, and adenosine deaminase (ADA1) activities in neonatal blood favor elevated extracellular adenosine. J Biol Chem (2013) 288(38):27315-26. doi:10.1074/jbc.M113. 484212

153. Jiang H, van de Ven C, Baxi L, Satwani P, Cairo MS. Differential gene expression signatures of adult peripheral blood vs cord blood monocyte-derived immature and mature dendritic cells. Exp Hematol (2009) 37(10):1201-15. doi:10.1016/j.exphem.2009.07.010

154. Satwani P, Morris E, van de Ven C, Cairo MS. Dysregulation of expression of immunoregulatory and cytokine genes and its association with the immaturity in neonatal phagocytic and cellular immunity. Biol Neonate (2005) 88(3):214-27. doi:10.1159/000087585

155. Lo-Man R. Regulatory B cells control dendritic cell functions. Immunotherapy (2011) 3(4 Suppl):19-20. doi:10.2217/imt.11.34

156. Cusumano V, Genovese F, Mancuso G, Carbone M, Fera MT, Teti G. Interleukin-10 protects neonatal mice from lethal group B streptococcal infection. Infect Immun (1996) 64(7):2850-2.

157. Madureira P, Andrade EB, Gama B, Oliveira L, Moreira S, Ribeiro A, et al. Inhibition of IL-10 production by maternal antibodies against Group B Streptococcus GAPDH confers immunity to offspring by favoring neutrophil recruitment. PLoS Pathog (2011) 7(11):e1002363. doi:10.1371/journal.ppat.1002363

158. Wrighting DM, Andrews NC. Interleukin-6 induces hepcidin expression through STAT3. Blood (2006) 108(9):3204-9. doi:10.1182/blood-2006-06027631

159. Frohm Nilsson M, Sandstedt B, Sorensen O, Weber G, Borregaard N, StahleBackdahl M. The human cationic antimicrobial protein (hCAP18), a peptide antibiotic, is widely expressed in human squamous epithelia and colocalizes with interleukin-6. Infect Immun (1999) 67(5):2561-6.

160. Kramer F, Torzewski J, Kamenz J, Veit K, Hombach V, Dedio J, et al. Interleukinlbeta stimulates acute phase response and $\mathrm{C}$-reactive protein synthesis by inducing an NFkappaB- and C/EBPbeta-dependent autocrine interleukin-6 loop. Mol Immunol (2008) 45(9):2678-89. doi:10.1016/j.molimm.2007.12.017 
161. Nagaki K, Hiramatsu S, Inai S, Sasaki A. The effect of aging on complement activity (CH50) and complement protein levels. J Clin Lab Immunol (1980) 3(1):45-50.

162. Lassiter HA. The role of complement in neonatal hypoxic-ischemic cerebral injury. Clin Perinatol (2004) 31(1):117-27. doi:10.1016/j.clp.2004.03.005

163. Schultz SJ, Aly H, Hasanen BM, Khashaba MT, Lear SC, Bendon RW, et al. Complement component 9 activation, consumption, and neuronal deposition in the post-hypoxic-ischemic central nervous system of human newborn infants. Neurosci Lett (2005) 378(1):1-6. doi:10.1016/j.neulet.2004. 12.008

164. Morley BJ, Walport M. The Complement Factsbook. San Diego, CA.: Academic Press (2000).

165. Frakking FN, Brouwer N, Zweers D, Merkus MP, Kuijpers TW, Offringa M, et al. High prevalence of mannose-binding lectin (MBL) deficiency in premature neonates. Clin Exp Immunol (2006) 145(1):5-12. doi:10.1111/j.13652249.2006.03093.x

166. Madsen HO, Garred P, Kurtzhals JA, Lamm LU, Ryder LP, Thiel S, et al. A new frequent allele is the missing link in the structural polymorphism of the human mannan-binding protein. Immunogenetics (1994) 40(1):37-44. doi:10.1007/BF00163962

167. Lau YL, Chan SY, Turner MW, Fong J, Karlberg J. Mannose-binding protein in preterm infants: developmental profile and clinical significance. Clin Exp Immunol (1995) 102(3):649-54. doi:10.1111/j.1365-2249.1995.tb03866.x

168. Dzwonek AB, Neth OW, Thiebaut R, Gulczynska E, Chilton M, Hellwig T, et al. The role of mannose-binding lectin in susceptibility to infection in preterm neonates. Pediatr Res (2008) 63(6):680-5. doi:10.1203/PDR. 0b013e31816fdbff

169. Frakking FN, Brouwer N, van Eijkelenburg NK, Merkus MP, Kuijpers TW, Offringa $\mathrm{M}$, et al. Low mannose-binding lectin (MBL) levels in neonates with pneumonia and sepsis. Clin Exp Immunol (2007) 150(2):255-62. doi:10.1111/ j.1365-2249.2007.03479.x

170. Koch A, Melbye M, Sorensen P, Homoe P, Madsen HO, Molbak K, et al. Acute respiratory tract infections and mannose-binding lectin insufficiency during early childhood. JAMA (2001) 285(10):1316-21. doi:10.1001/jama.285. 10.1316

171. Guinan EC, Barbon CM, Kalish LA, Parmar K, Kutok J, Mancuso CJ, et al. Bactericidal/permeability-increasing protein (rBPI21) and fluoroquinolone mitigate radiation-induced bone marrow aplasia and death. Sci Transl Med (2011) 3(110):110ra118. doi:10.1126/scitranslmed.3003126

172. Levin M, Quint PA, Goldstein B, Barton P, Bradley JS, Shemie SD, et al. Recombinant bactericidal/permeability-increasing protein (rBPI21) as adjunctive treatment for children with severe meningococcal sepsis: a randomised trial. rBPI21 Meningococcal Sepsis Study Group. Lancet (2000) 356(9234):961-7. doi:10.1016/S0140-6736(00)02712-4

173. Mansbach JM, Piedra PA, Borregaard N, Martineau AR, Neuman MI, Espinola JA, et al. Serum cathelicidin level is associated with viral etiology and severity of bronchiolitis. J Allergy Clin Immunol (2012) 130(4):1007-8e1. doi:10.1016/ j.jaci.2012.07.044

174. Kai-Larsen Y, Gudmundsson GH, Agerberth B. A review of the innate immune defence of the human fetus and newborn, with the emphasis on antimicrobial peptides. Acta Paediatr (2014). doi:10.1111/apa.12700

175. van Furth R, Schuit HR, Hijmans W. The immunological development of the human fetus. J Exp Med (1965) 122(6):1173-88. doi:10.1084/jem.122.6.1173

176. Raaphorst FM, van den Bergh R, Waaijer JL, Vossen JM, van Tol MJ. Expression of the human immunoglobulin heavy chain VH6 gene element by fetal B lymphocytes. Scand J Immunol (1997) 46(3):292-7.

177. Saji F, Samejima Y, Kamiura S, Koyama M. Dynamics of immunoglobulins at the feto-maternal interface. Rev Reprod (1999) 4(2):81-9. doi:10.1530/ror.0. 0040081

178. Simister NE. Placental transport of immunoglobulin G. Vaccine (2003) 21(24):3365-9. doi:10.1016/S0264-410X(03)00334-7

179. Gutierrez G, Gentile T, Miranda S, Margni RA. Asymmetric antibodies: a protective arm in pregnancy. Chem Immunol Allergy (2005) 89:158-68. doi:10.1159/000087964

180. Einarsdottir HK, Selman MH, Kapur R, Scherjon S, Koeleman CA, Deelder $\mathrm{AM}$, et al. Comparison of the Fc glycosylation of fetal and maternal immunoglobulin G. Glycoconj J (2013) 30(2):147-57. doi:10.1007/s10719012-9381-6
181. Linder N, Waintraub I, Smetana Z, Barzilai A, Lubin D, Mendelson E, et al. Placental transfer and decay of varicella-zoster virus antibodies in preterm infants. J Pediatr (2000) 137(1):85-9. doi:10.1067/mpd.2000.106902

182. Linder N, Sirota L, Aboudy Y, German B, Lifshits T, Barnea BS, et al. Placental transfer of maternal rubella antibodies to full-term and preterm infants. Infection (1999) 27(3):203-7. doi:10.1007/BF02561529

183. Mussi-Pinhata MM, Pinto PC, Yamamoto AY, Berencsi K, de Souza CB, Andrea $\mathrm{M}$, et al. Placental transfer of naturally acquired, maternal cytomegalovirus antibodies in term and preterm neonates. J Med Virol (2003) 69(2):232-9. doi:10.1002/jmv.10271

184. Hardy-Fairbanks AJ, Pan SJ, Decker MD, Johnson DR, Greenberg DP, Kirkland $\mathrm{KB}$, et al. Immune responses in infants whose mothers received Tdap vaccine during pregnancy. Pediatr Infect Dis J (2013) 32(11):1257-60. doi:10.1097/INF. 0b013e3182a09b6a

185. Kim D, Huey D, Oglesbee M, Niewiesk S. Insights into the regulatory mechanism controlling the inhibition of vaccine-induced seroconversion by maternal antibodies. Blood (2011) 117(23):6143-51. doi:10.1182/blood-2010-11320317

186. Crowe JE Jr. Influence of maternal antibodies on neonatal immunization against respiratory viruses. Clin Infect Dis (2001) 33(10):1720-7. doi:10.1086/ 322971

187. Idoko OT, Okolo SN, Plikaytis B, Akinsola A, Viviani S, Borrow R, et al. The impact of pre-existing antibody on subsequent immune responses to meningococcal A-containing vaccines. Vaccine (2014) 32(33):4220-7. doi:10.1016/j. vaccine.2014.04.052

188. Diez JJ, Iglesias $P$. The role of the novel adipocyte-derived hormone adiponectin in human disease. Eur J Endocrinol (2003) 148(3):293-300. doi:10.1530/eje.0. 1480293

189. Baumann H, Morella KK, White DW, Dembski M, Bailon PS, Kim H, et al. The full-length leptin receptor has signaling capabilities of interleukin 6type cytokine receptors. Proc Natl Acad Sci USA (1996) 93(16):8374-8. doi:10.1073/pnas.93.16.8374

190. Shapiro L, Scherer PE. The crystal structure of a complement-1q family protein suggests an evolutionary link to tumor necrosis factor. Curr Biol (1998) 8(6):335-8. doi:10.1016/S0960-9822(98)70133-2

191. Terrazzan AC, Procianoy RS, Silveira RC. Neonatal cord blood adiponectin and insulin levels in very low birth weight preterm and healthy full-term infants. JMatern Fetal Neonatal Med (2014) 27(6):616-20. doi:10.3109/14767058.2013. 823939

192. Bouman A, Heineman MJ, Faas MM. Sex hormones and the immune response in humans. Hum Reprod Update (2005) 11(4):411-23. doi:10.1093/humupd/ dmi008

193. Bouman A, Schipper M, Heineman MJ, Faas MM. Gender difference in the non-specific and specific immune response in humans. Am J Reprod Immunol (2004) 52(1):19-26. doi:10.1111/j.1600-0897.2004.00177.x

194. Oertelt-Prigione $S$. The influence of sex and gender on the immune response. Autoimmun Rev (2012) 11(6-7):A479-85. doi:10.1016/j.autrev.2011.11.022

195. Klein SL, Jedlicka A, Pekosz A. The Xs and Y of immune responses to viral vaccines. Lancet Infect Dis (2010) 10(5):338-49. doi:10.1016/S1473-3099(10) 70049-9

196. Cook IF. Sexual dimorphism of humoral immunity with human vaccines. Vaccine (2008) 26(29-30):3551-5. doi:10.1016/j.vaccine.2008.04.054

197. Fish EN. The X-files in immunity: sex-based differences predispose immune responses. Nat Rev Immunol (2008) 8(9):737-44. doi:10.1038/nri2394

198. Cutolo M, Seriolo B, Villaggio B, Pizzorni C, Craviotto C, Sulli A. Androgens and estrogens modulate the immune and inflammatory responses in rheumatoid arthritis. Ann N Y Acad Sci (2002) 966:131-42. doi:10.1111/j.1749-6632. 2002.tb04210.x

199. Piccinni MP, Giudizi MG, Biagiotti R, Beloni L, Giannarini L, Sampognaro $\mathrm{S}$, et al. Progesterone favors the development of human $\mathrm{T}$ helper cells producing Th2-type cytokines and promotes both IL-4 production and membrane CD30 expression in established Th1 cell clones. J Immunol (1995) 155(1):128-33.

200. Piccinni MP, Scaletti C, Maggi E, Romagnani S. Role of hormone-controlled Th1- and Th2-type cytokines in successful pregnancy. J Neuroimmunol (2000) 109(1):30-3. doi:10.1016/S0165-5728(00)00299-X

201. Elmlinger MW, Kuhnel W, Ranke MB. Reference ranges for serum concentrations of lutropin (LH), follitropin (FSH), estradiol (E2), prolactin, 
progesterone, sex hormone-binding globulin (SHBG), dehydroepiandrosterone sulfate (DHEAS), cortisol and ferritin in neonates, children and young adults. Clin Chem Lab Med (2002) 40(11):1151-60. doi:10.1515/CCLM. 2002.202

202. Desoye G, Schweditsch MO, Pfeiffer KP, Zechner R, Kostner GM. Correlation of hormones with lipid and lipoprotein levels during normal pregnancy and postpartum. J Clin Endocrinol Metab (1987) 64(4):704-12. doi:10.1210/jcem64-4-704

203. Lewis CE, Funkhouser E, Raczynski JM, Sidney S, Bild DE, Howard BV. Adverse effect of pregnancy on high density lipoprotein (HDL) cholesterol in young adult women. The CARDIA Study. coronary artery risk development in young adults. Am J Epidemiol (1996) 144(3):247-54. doi:10.1093/oxfordjournals.aje. a008919

204. Loke DF, Viegas OA, Kek LP, Rauff M, Thai AC, Ratnam SS. Lipid profiles during and after normal pregnancy. Gynecol Obstet Invest (1991) 32(3):144-7. doi:10.1159/000293016

205. Bastida S, Perea S, Sanchez-Muniz FJ. Do neonates with high serum cholesterol levels have a different high density lipoprotein composition? Eur J Pediatr (1998) 157(1):66-70. doi:10.1007/s004310050769

206. Kharb S, Kaur R, Singh V, Sangwan K. Birth weight, cord blood lipoprotein and apolipoprotein levels in Indian newborns. Int J Prev Med (2010) 1(1):29-33.

207. Feingold KR, Memon RA, Moser AH, Grunfeld C. Paraoxonase activity in the serum and hepatic mRNA levels decrease during the acute phase response. Atherosclerosis (1998) 139(2):307-15. doi:10.1016/S0021-9150(98) 00084-7

208. Wurfel MM, Kunitake ST, Lichenstein H, Kane JP, Wright SD. Lipopolysaccharide (LPS)-binding protein is carried on lipoproteins and acts as a cofactor in the neutralization of LPS. J Exp Med (1994) 180(3):1025-35. doi:10.1084/jem. 180.3.1025

209. Kaji H. High-density lipoproteins and the immune system. J Lipids (2013) 2013:684903. doi:10.1155/2013/684903

210. Cockerill GW, Rye KA, Gamble JR, Vadas MA, Barter PJ. High-density lipoproteins inhibit cytokine-induced expression of endothelial cell adhesion molecules. Arterioscler Thromb Vasc Biol (1995) 15(11):1987-94. doi:10.1161/01. ATV.15.11.1987

211. Laskowitz DT, Lee DM, Schmechel D, Staats HF. Altered immune responses in apolipoprotein E-deficient mice. J Lipid Res (2000) 41(4):613-20.

212. Zhang HL, Wu J, Zhu J. The immune-modulatory role of apolipoprotein $\mathrm{E}$ with emphasis on multiple sclerosis and experimental autoimmune encephalomyelitis. Clin Dev Immunol (2010) 2010:186813.doi:10.1155/2010/ 186813

213. Landi A, Babiuk LA, van Drunen Littel-van den Hurk S. Dendritic cells matured by a prostaglandin E2-containing cocktail can produce high levels of IL12 p70 and are more mature and Th1-biased than dendritic cells treated with TNF-alpha or LPS. Immunobiology (2011) 216(6):649-62. doi:10.1016/j.imbio. 2010.11.004

214. Muthuswamy R, Mueller-Berghaus J, Haberkorn U, Reinhart TA, Schadendorf D, Kalinski P. PGE(2) transiently enhances DC expression of CCR7 but inhibits the ability of DCs to produce CCL19 and attract naive T cells. Blood (2010) 116(9):1454-9. doi:10.1182/blood-2009-12-258038

215. Shimabukuro-Vornhagen A, Liebig TM, Koslowsky T, Theurich S, von Bergwelt-Baildon MS. The ratio between dendritic cells and T cells determines whether prostaglandin E has a stimulatory or inhibitory effect. Cell Immunol (2013) 281(1):62-7. doi:10.1016/j.cellimm.2013.01.001

216. Rodriguez M, Domingo E, Municio C, Alvarez Y, Hugo E, Fernandez N, et al. Polarization of the innate immune response by prostaglandin E2: a puzzle of receptors and signals. Mol Pharmacol (2014) 85(1):187-97. doi:10.1124/mol. 113.089573

217. Yao C, Sakata D, Esaki Y, Li Y, Matsuoka T, Kuroiwa K, et al. Prostaglandin E2-EP4 signaling promotes immune inflammation through Th1 cell differentiation and Th17 cell expansion. Nat Med (2009) 15(6):633-40. doi:10.1038/ nm. 1968

218. Zaitseva M, Romantseva T, Blinova K, Beren J, Sirota L, Drane D, et al. 159Use of human MonoMac6 cells for development of in vitro assay predictive of adjuvant safety in vivo. Vaccine (2012) 30(32):4859-65. doi:10.1016/j.vaccine. 2012.05.002

219. Geissmann F, Revy P, Brousse N, Lepelletier Y, Folli C, Durandy A, et al. Retinoids regulate survival and antigen presentation by immature dendritic cells. J Exp Med (2003) 198(4):623-34. doi:10.1084/jem.20030390
220. Carman JA, Smith SM, Hayes CE. Characterization of a helper T lymphocyte defect in vitamin A-deficient mice. J Immunol (1989) 142(2):388-93.

221. Houghton LA, Vieth R. The case against ergocalciferol (vitamin D2) as a vitamin supplement. Am J Clin Nutr (2006) 84(4):694-7.

222. Abrams SA, Coss-Bu JA, Tiosano D. Vitamin D: effects on childhood health and disease. Nat Rev Endocrinol (2013) 9(3):162-70. doi:10.1038/nrendo.2012.259

223. Wintergerst ES, Maggini S, Hornig DH. Immune-enhancing role of vitamin C and zinc and effect on clinical conditions. Ann Nutr Metab (2006) 50(2):85-94. doi:10.1159/000090495

224. Filippini A, Taffs RE, Sitkovsky MV. Extracellular ATP in T-lymphocyte activation: possible role in effector functions. Proc Natl Acad Sci USA (1990) 87(21):8267-71. doi:10.1073/pnas.87.21.8267

225. Schenk U, Westendorf AM, Radaelli E, Casati A, Ferro M, Fumagalli M, et al. Purinergic control of T cell activation by ATP released through pannexin-1 hemichannels. Sci Signal (2008) 1(39):ra6. doi:10.1126/scisignal.1160583

226. Baricordi OR, Ferrari D, Melchiorri L, Chiozzi P, Hanau S, Chiari E, et al. An ATP-activated channel is involved in mitogenic stimulation of human T lymphocytes. Blood (1996) 87(2):682-90.

227. Baricordi OR, Melchiorri L, Adinolfi E, Falzoni S, Chiozzi P, Buell G, et al. Increased proliferation rate of lymphoid cells transfected with the P2X(7) ATP receptor. J Biol Chem (1999) 274(47):33206-8. doi:10.1074/jbc.274.47.33206

228. Sud'ina GF, Mirzoeva OK, Galkina SI, Pushkareva MA, Ullrich V. Involvement of ecto-ATPase and extracellular ATP in polymorphonuclear granulocyteendothelial interactions. FEBS Lett (1998) 423(2):243-8. doi:10.1016/S00145793(98)00102-1

229. Balazovich KJ, Boxer LA. Extracellular adenosine nucleotides stimulate protein kinase C activity and human neutrophil activation. J Immunol (1990) 144(2):631-7.

230. Cockcroft S, Stutchfield J. ATP stimulates secretion in human neutrophils and HL60 cells via a pertussis toxin-sensitive guanine nucleotide-binding protein coupled to phospholipase C. FEBS Lett (1989) 245(1-2):25-9. doi:10.1016/ 0014-5793(89)80184-X

231. Chen Y, Shukla A, Namiki S, Insel PA, Junger WG. A putative osmoreceptor system that controls neutrophil function through the release of ATP, its conversion to adenosine, and activation of A2 adenosine and $\mathrm{P} 2$ receptors. J Leukoc Biol (2004) 76(1):245-53. doi:10.1189/jlb.0204066

232. Bours MJ, Swennen EL, Di Virgilio F, Cronstein BN, Dagnelie PC. Adenosine 5 '-triphosphate and adenosine as endogenous signaling molecules in immunity and inflammation. Pharmacol Ther (2006) 112(2):358-404. doi:10.1016/ j.pharmthera.2005.04.013

233. Trautmann A. Extracellular ATP in the immune system: more than just a "danger signal”. Sci Signal (2009) 2(56):e6. doi:10.1126/scisignal.256pe6

234. Robson SC, Sevigny J, Zimmermann H. The E-NTPDase family of ectonucleotidases: structure function relationships and pathophysiological significance. Purinergic Signal (2006) 2(2):409-30. doi:10.1007/s11302-006-9003-5

235. Yegutkin GG. Nucleotide- and nucleoside-converting ectoenzymes: important modulators of purinergic signalling cascade. Biochim Biophys Acta (2008) 1783(5):673-94. doi:10.1016/j.bbamcr.2008.01.024

236. Ota MO, Vekemans J, Schlegel-Haueter SE, Fielding K, Sanneh M, Kidd M, et al. Influence of Mycobacterium bovis bacillus Calmette-Guerin on antibody and cytokine responses to human neonatal vaccination. J Immunol (2002) 168(2):919-25. doi:10.4049/jimmunol.168.2.919

Conflict of Interest Statement: The authors declare that the research was conducted in the absence of any commercial or financial relationships that could be construed as a potential conflict of interest.

Received: 17 July 2014; accepted: 08 September 2014; published online: 24 September 2014.

Citation: Pettengill MA, van Haren SD and Levy O (2014) Soluble mediators regulating immunity in early life. Front. Immunol. 5:457. doi: 10.3389/fimmu.2014.00457 This article was submitted to Immunotherapies and Vaccines, a section of the journal Frontiers in Immunology.

Copyright (c) 2014 Pettengill, van Haren and Levy. This is an open-access article distributed under the terms of the Creative Commons Attribution License (CC BY). The use, distribution or reproduction in other forums is permitted, provided the original author(s) or licensor are credited and that the original publication in this journal is cited, in accordance with accepted academic practice. No use, distribution or reproduction is permitted which does not comply with these terms. 